\title{
Cmentarz, trup i dusza w wyobrażeniach prasy kaliskiej drugiej połowy XIX wieku
}

Streszczenie. Cmentarz - zinstytucjonalizowane miejsce składania zwłok, w znanej dziś formie jest efektem rewolucyjnych przemian, jakie przyniosło Europie oświecenie. Ich główną cechą jest lokowanie nekropolii z dala od ludzkich osiedli. Urzędowa akcja przenoszenia cmentarzy zbiegła się z potrzebą kultywowania pamięci o bliskich zmarłych. Tak rewolucyjne zmiany nie mogły pozostać bez wpływu na postrzeganie śmierci. Artykuł jest próbą naszkicowania poglądów, wierzeń i fantazji na temat cmentarzy chrześcijańskich wśród inteligencji kaliskiej w II połowie XIX wieku. Zebrany materiał źródłowy pochodzi z wychodzącego w latach 1871-1892 „Kaliszanina”. Większość analizowanych tekstów dotyczy nekropolii kaliskich, ale nie pominięto też wypowiedzi dotyczących innych miast i zawartych w fikcji literackiej. Ze względu na obszerność problematyki skupiono się na trzech wybranych problemach. W centrum zainteresowań stoi postrzeganie nekropolii i ich „mieszkańców” - zmarłych. Cmentarze są miejscem przeznaczonym do składowania ludzkich szczątków i kultywowania pamięci o zmarłych. Jednak przez związki z eschatologią są miejscami wymykającymi się kategoriom racjonalnym. Wynikająca z tego niejednoznaczność niewątpliwie warta jest uwagi badaczy. Sporo uwagi poświęcono postrzeganiu przez ludzi II połowie XIX wieku szczątków już złożonych w grobie. Jest to tytułowy „trup”. Kolejnym obszarem zainteresowania jest dusza - hipotetyczna forma egzystencji pośmiertnej ludzi. W kulturze chrześcijańskiej wiara w zmartwychwstałe ciała jest ściśle związana z wiarą w nieśmiertelną duszę. Cmentarz jest nie tylko miejscem złożenia oczekujących na zmartwychwstanie ciał, ale również strefą, w której mogą ukazać się ludziom „duchy”. Stąd nie sposób pominąć poglądów i fantazji na ten temat. Dokonano przy tym próby interpretacji zebranego materiału, mając nadzieję, że przyczynek ten będzie przydatny do dalszych badań nad zagadnieniem.

Słowa kluczowe: cmentarze, eschatologia, zwłoki, dusza, Kalisz, prasa, „Kaliszanin”, Chodyński Adam. 
dea cmentarza - zinstytucjonalizowanego miejsca składania ludzkich zwłok - w znanej po dziś dzień formie jest efektem rewolucyjnych przemian, jakie przyniosło Europie oświecenie ${ }^{1}$. Zamykano użytkowane od średniowiecza nekropolie przykościelne, a cmentarze zaczęto lokować z dala od siedzib ludzkich. Urzędowa akcja, motywowana względami sanitarnymi, zbiegła się z potrzebą kultywowania pamięci o bliskich zmarłych i związanym z nią zwyczajem „odwiedzania” zmarłych. Miejsce złożenia ciała stało się miejscem pamięci i modlitwy, które należało oznaczyć, uchronić przed przekopaniem i pochówkiem „obcego” zmarłego. Dążono do tego, aby „grób” - miejsce, wokół którego zbierają się bliscy - miał możliwie estetyczny wygląd. Każdy zmarły powinien był mieć grób indywidualny lub dzielony z bliskimi, nawet jeśli finanse rodziny pozwalały tylko na kopczyk obłożony darnią i drewniany krzyż. Estetyka i dbałość miały być wyrazem uczuć do zmarłego, choć szybko stały się też pokazem możliwości finansowych. Proces tworzenia się cmentarzy w dzisiejszej postaci nie był wynikiem jednorazowego aktu, ale skutkiem powolnych zmian trwających często do II połowy XIX wieku. W ich wyniku nekropolia przybrała postać sentymentalnego parku łączącego harmonijnie dzieła przyrody i człowieka - stąd popularne określenie „ogrody snu i pamięci”.

Tak potężna, choć nie jednorazowa zmiana, nie mogła pozostać bez wpływu na postrzeganie samych nekropolii i samych zmarłych. Tekst jest próbą naszkicowania, w jaki sposób postrzegane były cmentarze chrześcijańskie i wierzenia eschatologiczne z nimi związane przez inteligencję prowincjonalnego miasta w II połowie XIX wieku. Z racji chrześcijańskiej nauki o zmartwychwstaniu ciała pewną uwagę poświęcono kwestii zwłok - trupa w grobie. Zebrany materiał źródłowy pochodzi z prasy kaliskiej - wychodzącego w latach 1871-1892 „Kaliszanina”. Brak w nim niestety wypowiedzi księży i innych niż inteligencja warstw społecznych, nieobecni są też protestanci i prawosławni. W dodatku najsilniejszy głos należy do kaliskiego prawnika, historyka, regionalisty, dziennikarza i literata Adama Chodyńskiego². Ryzyko, że patrzymy na przeszłość przez pryzmat jego spojrzenia, jest tym większe,

\footnotetext{
Proces ten został już wielokrotnie przedstawiony. Szerzej można się z nim zapoznać w klasycznych już pozycjach, takich jak: Aries 1989, KolbuszewsKi 1996, KolbuszewsKi 1985, Vovelle 2008. Informacje te powtarzają często również opracowania o historii poszczególnych nekropolii, np. NiCIEJA 2010.

2 Adam Chodyński (1832-1902) - prawnik, historyk, założyciel gazety „Kaliszanin”, dziennikarz, regionalista, pisarz i poeta. W młodości zajmował się historią literatury, następnie historią rodzinnego Kalisza i regionu, tworząc szereg prac poświęconych tej tematyce. Obok prac wydanych w formie książkowej większość dzieł Chodyńskiego wydrukowano na łamach „Kaliszanina”. Jako dziennikarz interesował się problemami Kalisza, ale często sięgał po tematykę z różnych dziedzin życia, np. kwestię kobiecą, prawo, opiekę nad zwierzętami. Poezja i proza Chodyńskiego uważana jest za najmniej interesującą i wartościową część jego działalności pisarskiej. Biografię Adama Chodyńskiego opublikował: WALCZAK 2010.
} 


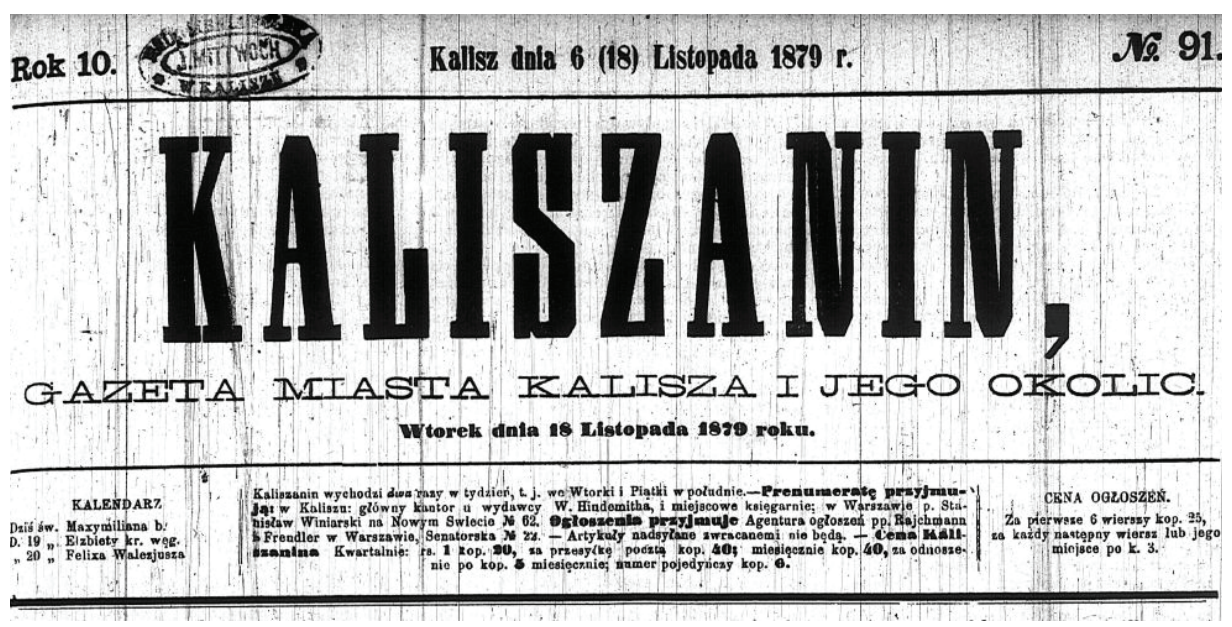

1. Winieta „Kaliszanina" z 1879, nr 91

iż pewna część przytoczonych anonimowych tekstów mogła być również jego pióra $^{3}$. Z tej racji postaci Chodyńskiego należy się parę słów przybliżenia. Należy podkreślić wyniesioną $\mathrm{z}$ domu religijność tego najbardziej znanego $\mathrm{z}$ kaliskich regionalistów. Dwóch braci Adama obrało stan duchowny ${ }^{4}$. Melancholijny charakter i tragiczne losy rodziny z pewnością przyczyniły się do przebijającej z jego tekstów fascynacji śmiercią̧ $\mathrm{Z}$ pewną ostrożnością można uznać, że zebrany materiał reprezentuje wyobrażenia inteligencji prowincjonalnego miasta. Inteligencji wyznania katolickiego lub mniej religijnej, ale wywodzącej się z katolickich rodzin.

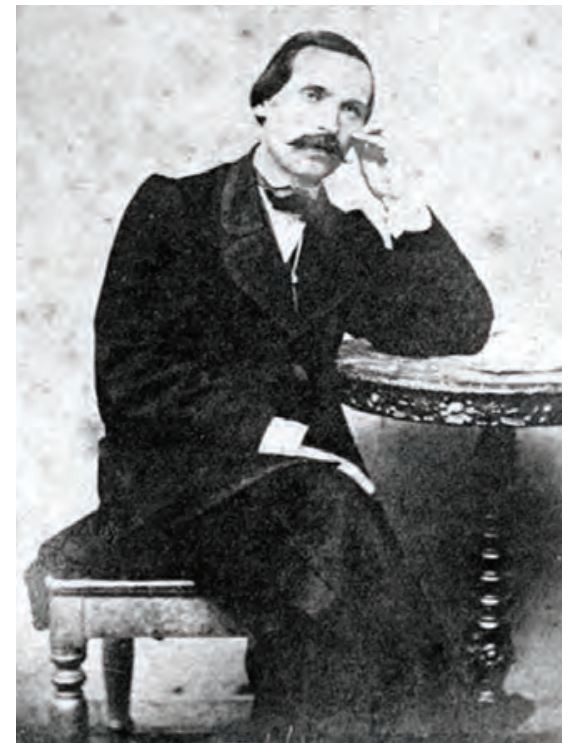

2. Adam Chodyński (1832-1902) kaliski prawnik, historyk, dziennikarz, regionalista, literat Fot. w zbiorach Muzeum Okręgowego Ziemi Kaliskiej

\footnotetext{
Chyba nie przesadzona jest opinia Polanowskiego, że Chodyński niejednokrotnie sam zapełniał numer gazety. Por. PolANOWSKI 1979, s. 305.

4 Ks. Zenon (1836-1887) i ks. Stanisław (1836-1919) osiągnęli wysokie godności kościelne, m.in. kanoników włocławskich.

W 1866 roku w niewyjaśnionych do dziś okolicznościach zmarła ukochana żona historyka, następnie w 1867 zmarło jego dwóch synów, w 1885 roku od ciosu sztyletem zginął najstarszy z synów, a w 1889 roku ostatni męski potomek historyka. Por. WALCZAK 2010, s. 31-32.
} 


\section{Kalisz i jego pozamiejskie nekropolie}

Do Kalisza nowe idee dotyczące zmarłych docierają pod koniec XVIII wieku. Pierwszym ich objawem jest zarządzenie Komisji Dobrego Porządku z 16 lutego 1787 roku, zakazujące chowania na cmentarzach przykościelnych w murach miasta. Zostanie ono kilkakrotnie powtórzone, aż wreszcie 4 kwietnia 1803 roku pruska „kamera wojenno-ekonomiczna” w Kaliszu wyda rygorystyczne przepisy w tej kwestii. W tym czasie zmarli chowani są na małych cmentarzach przykościelnych ulokowanych w pobliżu miasta ${ }^{6}$.

W 1807 roku poza granicami miasta, za Rogatką Wrocławską, zostaje założony katolicki cmentarz nazywany Cmentarzem Miejskim. Nekropolia do dziś sąsiaduje z dwoma starszymi cmentarzami - protestanckim (wzmiankowany w 1689 roku) i prawosławnym (założony w 1786 roku). Pozamiejskie położenie tych ostatnich nie wynika z oświeceniowych idei sanitarnych - aż do 1787 roku katolicy chowani są w obrębie murów miejskich. Usytuowanie z dala od miasta należy raczej rozumieć w kategoriach wykluczenia wyznań niekatolickich, choć w praktyce w murach miasta nie było już możliwości stworzenia nowych miejsc grzebalnych. Pojawienie się w 1807 roku w sąsiedztwie cmentarza prawosławnego i protestanckiego nekropolii katolickiej staje się wyrazem równouprawnienia wyznań. Z pierwszej ćwierci XIX wieku pochodzą najstarsze zachowane pomniki nagrobne. Z czasem nekropolie zaczną się wypełniać licznymi nagrobkami i grobowcami rodzinnymi, i staną się wielkim cmentarzyskiem chrześcijańskiej ludności Kalisza

W interesującej nas epoce, dokładnie od roku 1867, Kalisz jest jednym z dziesięciu gubernialnych miast Królestwa Polskiego. W 1851 roku ludność miasta osiągnie liczbę 11430 mieszkańców i liczba ta będzie stopniowo rosnąć, aby dojść do 23882 osób. Rozwojowi gospodarczemu sprzyja nadgraniczne położenie. Ułatwia ono kontakty kulturalne np. z niemieckim Wrocławiem. Ówczesny Kalisz ma charakter wielokulturowy, z dużą mniejszością żydowską i niemiecką. Mniejszość rosyjska to liczni urzędnicy i wojskowi, ale też żołnierze stacjonującego tu garnizonu. W mieście oprócz pięciu kościołów katolickich i kaplic przy instytucjach szpitalno-dobroczynnych znajduje się sobór prawosławny, cerkiew wojskowa, dwie synagogi (w tym reformowana) i kościół ewangelicki. Kalisz jest dość prężnym ośrodkiem kultury z teatrem (bez stałej siedziby), drukarnią i wydawaną od 1870 roku gazetą „Kaliszanin”. Rozwój ekonomiczny miasta wstrzymuje brak kolei żelaznej.

\footnotetext{
Szerzej na temat procesu przenoszenia cmentarzy poza mury Kalisza MAŁYsZKo 2012, s. 29-30 i 147-148 oraz BŁACHOWICZ 2003, s. 89-94.

Historia cmentarzy kaliskich m.in. MAŁYSZKO 2010, BŁACHOWICZ 2003.

8 Atmosferę ówczesnego Kalisza opisuje m.in. Polanowski 1979, IDEM 1987, Kunicki 1991, PRZYGODZKI 2012.
} 


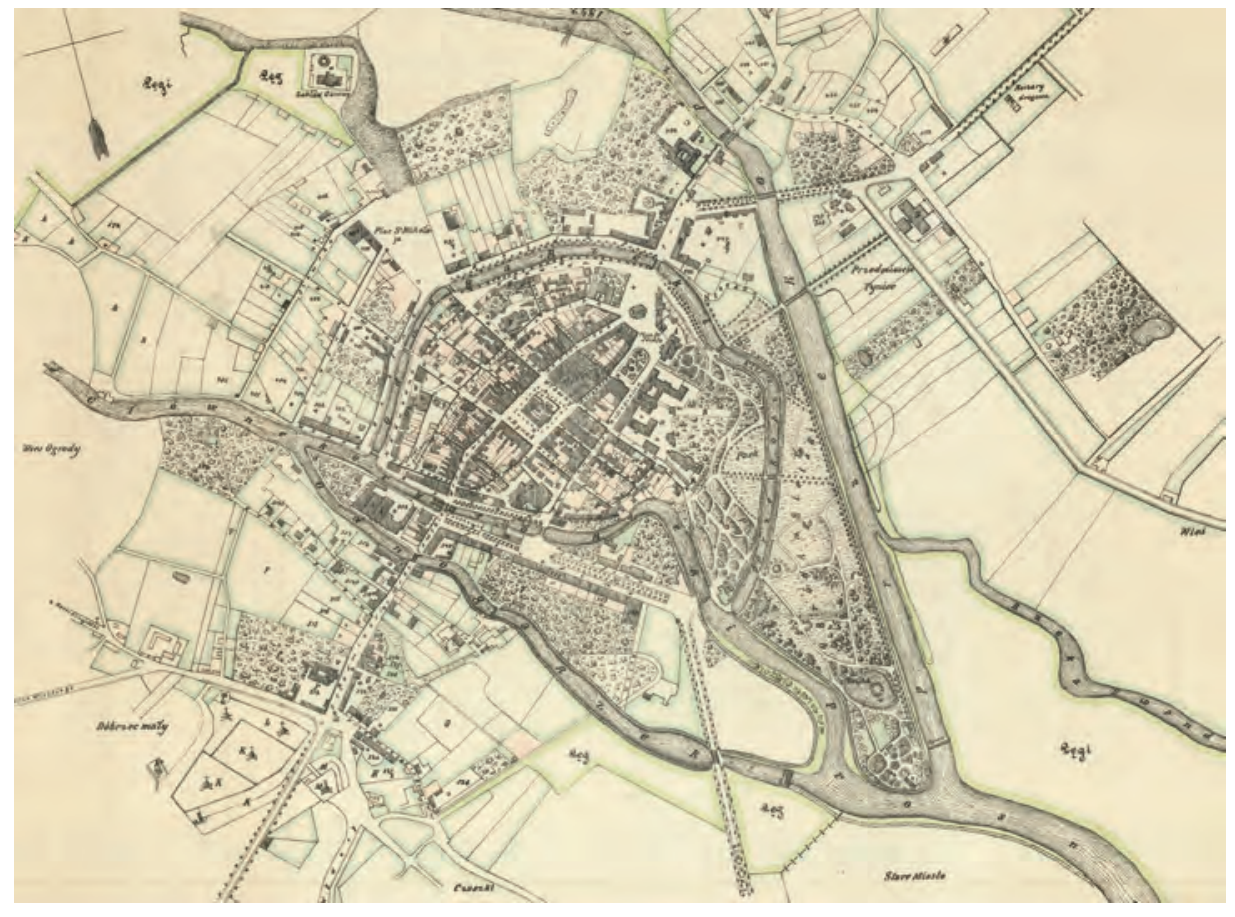

3. Plan Kalisza z 1878 roku z zaznaczonymi (lewy dolny róg) cmentarzami przy Rogatce Fragment planu miasta z $1878 \mathrm{r}$

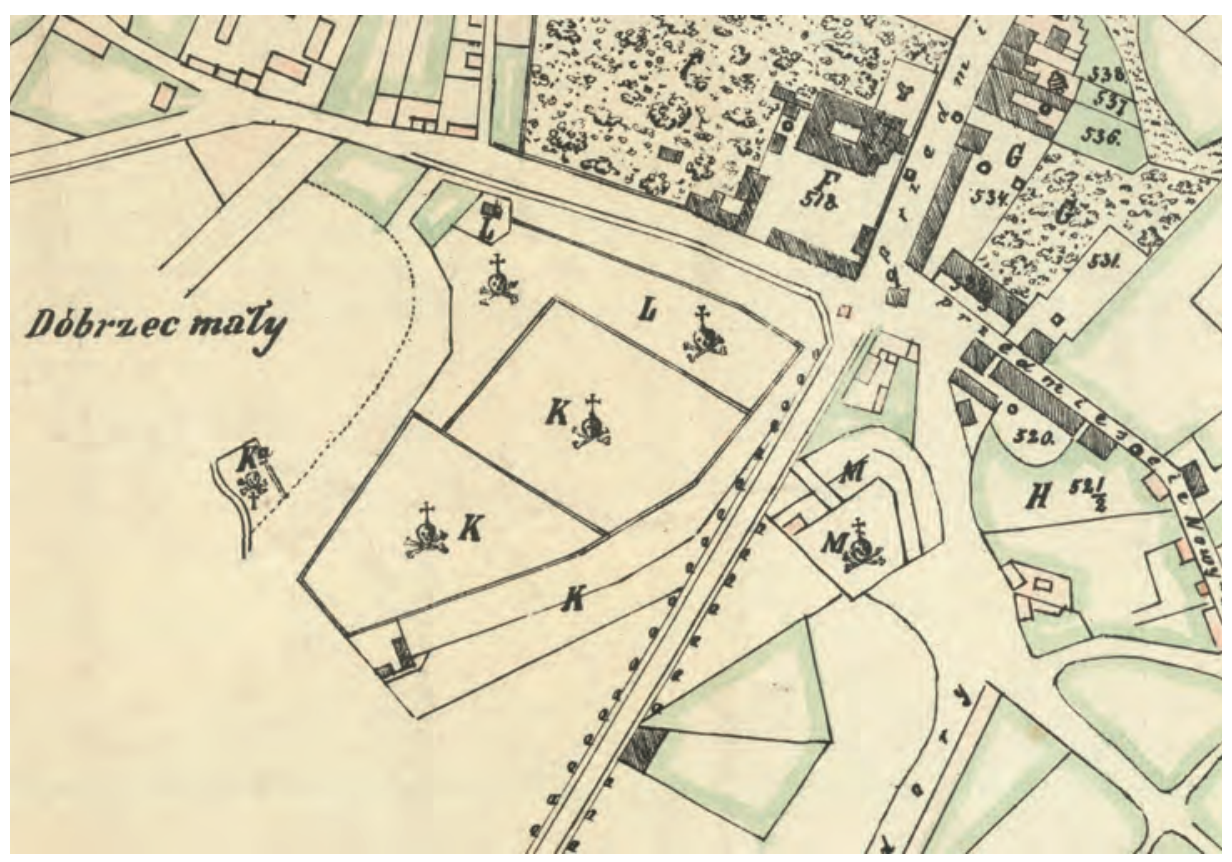

4. Cmentarze przy Rogatce $w$ Kaliszu, fragment planu z 1878 r.: K - cmentarze katolickie, Ka - cmentarz choleryczny, L-cmentarz ewangelicki, M - cmentarz prawosławny. Fragment planu miasta z $1878 \mathrm{r}$. 


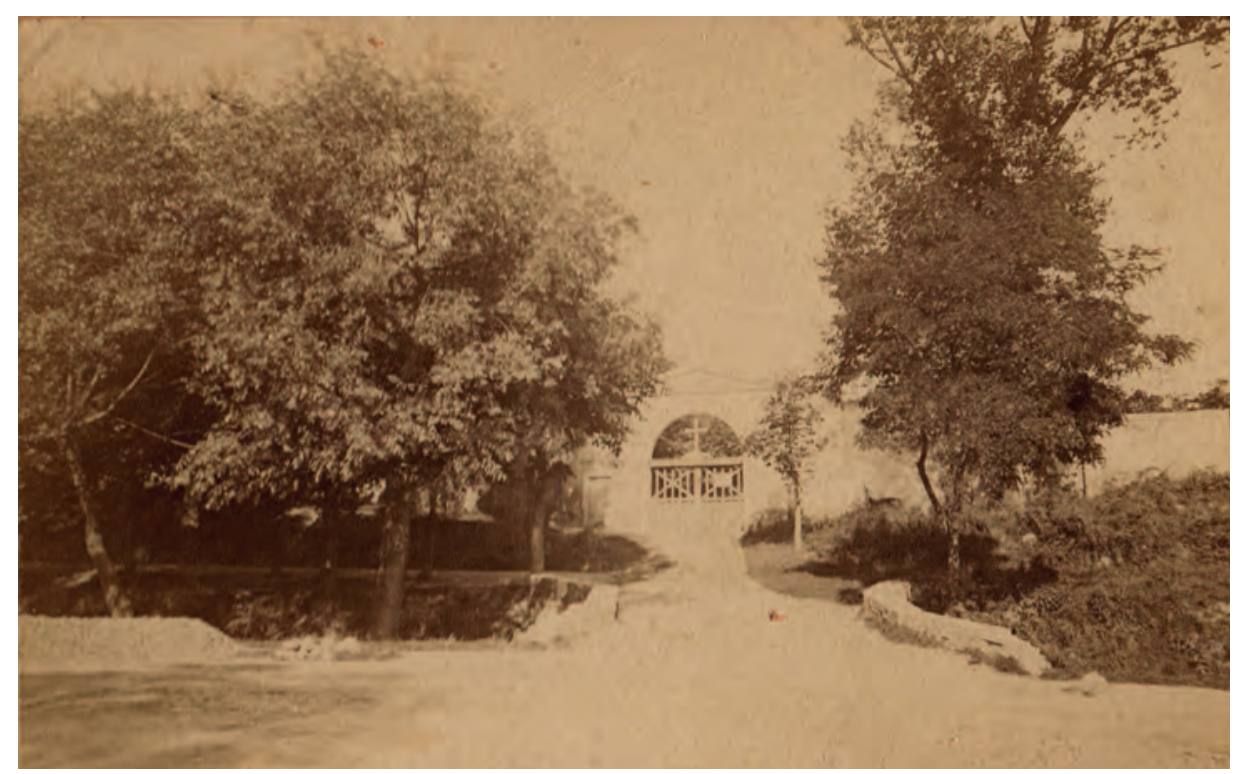

5. Wejście na Cmentarz Miejski w Kaliszu w latach 70. XIX wieku. Fot. z „Albumu de Kalisch” Jeana Guilaume Diehla ze zbiorów Miejskiej Biblioteki Publicznej im. A. Asnyka w Kaliszu

\section{Cmentarze - miasta umarłych}

W okresie tym wszystkie trzy cmentarze przy Rogatce są już w pełni ukształtowane, tj. posiadają ogrodzenie, bramy, kaplice przedpogrzebowe i mieszkania dla służby cmentarnej. Oprócz tej infrastruktury nekropolie posiadają zieleń, a pochówki dzielą się na trwałe (pomniki, grobowce i kaplice rodzinne) i czasowe, czyli ziemne. W drugiej połowie XIX wieku cmentarz jest ważną instytucją użytku publicznego, taką jak budowle publiczne, parki czy wodociągi. Fakt, że jest rozplanowany, posiada drogi i ścieżki, a przy nich niczym domy wznoszą się grobowce i kaplice, pozwala współczesnym snuć fantazję, że cmentarz jest „nekropolis”, miastem umarłych. Tu jest nekropolis - tu jest miasto umarlych $w$ którem spopieliły się na zawsze nieprzeliczone względnostki ${ }^{9}$, pisze w swoim opowiadaniu (1888) Adam Chodyński. Dostrzega się w nim nie tylko miejsce pochówku, ale też niezwykle atrakcyjną przestrzeń ogrodową. Takim chce widzieć Cmentarz Miejski redaktor „Kaliszanina” (1877):

Rzadko które miasto posiada tak pięknie utrzymany i w tak uroczej miejscowości położony cmentarz jak nasz. Ten gród umarłych, mieszczący w sobie popioły tylu drogich nam osób, szczególniejszą troskliwością otaczają żywi. Mnóstwo

9 Kaliszanin 1888, Nr 13. 
drzew, w których cieniu liczne chronią się groby, więcej jeszcze zdobiących je kwiatów, napełniających balsamiczną wonią powietrze i stojące na mogiłach pomniki i krzyże, nadają tej miejscowości dziwnie piękną i smętną zarazem powierzchowność ${ }^{10}$.

Po takich cmentarzach chętnie się spaceruje: znamy wiele osób, które miejsce to przedkładaja nad park nasz uroczy, $i$ tu przepędzaja przeznaczone na odpoczynek godziny, rozmyślając nad znikomością rzeczy ziemskich ${ }^{11}$.

Cmentarze są dla autora nie tylko piękne, ale też „dziwnie piękne”. Dziwność ta, jak można przypuszczać, polega na postrzeganiu rzeczy smutnych jako estetycznie pociągające. Na bliskość piękna i śmierci zwraca uwagę Michel Vovelle, przytaczając wiersz Wiktora Hugo, w którym piękno i śmierć przedstawione są jako dwie siostry. Zdaniem Hugo łączy je tajemnica, „zagadka ich bytu” ${ }^{12}$. O estetyzacji śmierci czy wręcz „ukryciu się jej pod pięknem” pisze Philippe Aries ${ }^{13}$. Dla Adama Dobrowolskiego, warszawskiego korespondenta „Kaliszanina”: cmentarz powazkowski dziwne [...] sprawia wrażenie. Myśl odrywa się od poziomej prozy, która ustawicznie mamy przed oczami. Kontrast między rozwijajaca się, pełną nadziei natura a umarłym światem, zawiera cały majestat poetycznej grozy $(1884)^{14}$.

Nic dziwnego, że miejsce tak związane ze śmiercią wymaga poetyckiego potraktowania (1871):

\begin{abstract}
Cmentarz ewangelicki [w Kaliszu - przyp. M.B.] naszego miasta wygląda o tej porze jak kosz zieleni i kwiecia. Czystość, wzorcowy porządek, woń balsamiczna i pewien urok miłego smętku, tchnące na owem wzgórzu grobów - nęcą nieomal do śmierci. To miejsce wiecznego spokoju po burzach życia, piękność swą zawdzięcza nieustającej o nie troskliwości pana Szliwe $[\ldots]^{15}$.
\end{abstract}

Charakterystyczne, że piękno, czyli „uroda cmentarza”, „nęci” autora nieomal do śmierci. Świat żywych jest światem walki (burzy) i ciągłym pobojowiskiem, na cmentarzu panuje nieznany żywym spokój. Równolegle w tekście pojawiają się wątki wskazujące na utylitarny charakter nekropolii. Nie jest ona dziełem natury, a człowieka, ,troskliwego pana Szliwe”, który jako główny członek dozoru [...] nie szczędzi wszelkich troskliwych upiększeń, tak przynależnych prochom tych, co już

\footnotetext{
KALiSZANin 1877, NR 67.

KalisZanin 1877, NR 67.

VOVELle 2008, s. 558-559.

ARIES 1989, s. 463.

Kaliszanin 1884, NR 48.

KalisZanin 1871, NR 45.
} 


\section{TECHNE \\ T E X N H \\ SERIA NOWA

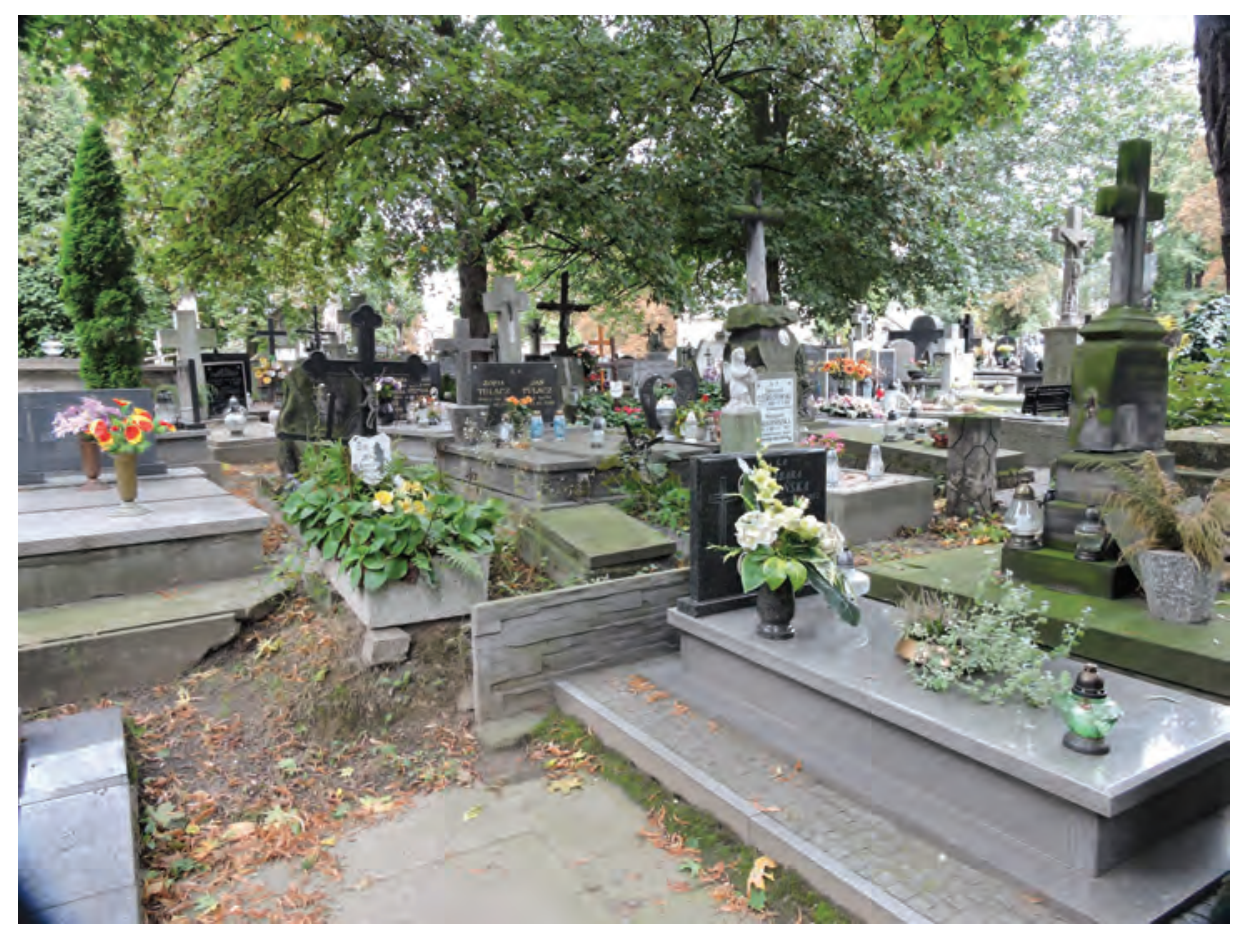

6. Cmentarz katolicki w Kaliszu - fragment. Fot. K. Stefański, 2017

zeszli $z$ wielkiego pobojowiska $\dot{z} y c i a^{16}$. Poezja miesza się z opisem funkcjonowania instytucji cmentarnej i zastosowanych rozwiązań (1871):

Zawdzięcza to cmentarz mądrym urządzeniom. Za miejsca np. płaci się nieco więcej, a za to fundusz obracany jest na upiększenie, na restaurację [...] tu nie widać owych smutnych rozsypujących się mogił, którym natura trawki, a ludzie odmówili pamięci. Jak nie widzimy ruiny nagrobków i sklepów, tak również każdą mogiłkę ziemi okrywa bogaty płaszcz zieloności i kwiecia. Dostaje się więc i ubogim, to co gdzie indziej mają szczątki tylko bogatych: dostaje się ciche i rzewne słowo pamięci, które do żywych przemawia zielenią murawy i wonią kwiatów, czem wszystkiem kieruje osobiście niezmordowany p. Szliwe ${ }^{17}$.

Cmentarz staje się miejscem lepszym niż pełen nierówności świat żywych. Dobre zarządzanie nekropolią pozwala na szacunek dla wszystkich zmarłych - niezależnie od statusu. Szacunek ten wyraża się opieką nad wszystkimi bez wyjątku grobami. To nie koniec rozwiązań w duchu utylitaryzmu (1871):

\footnotetext{
16 Ibidem.

17 Ibidem.
} 


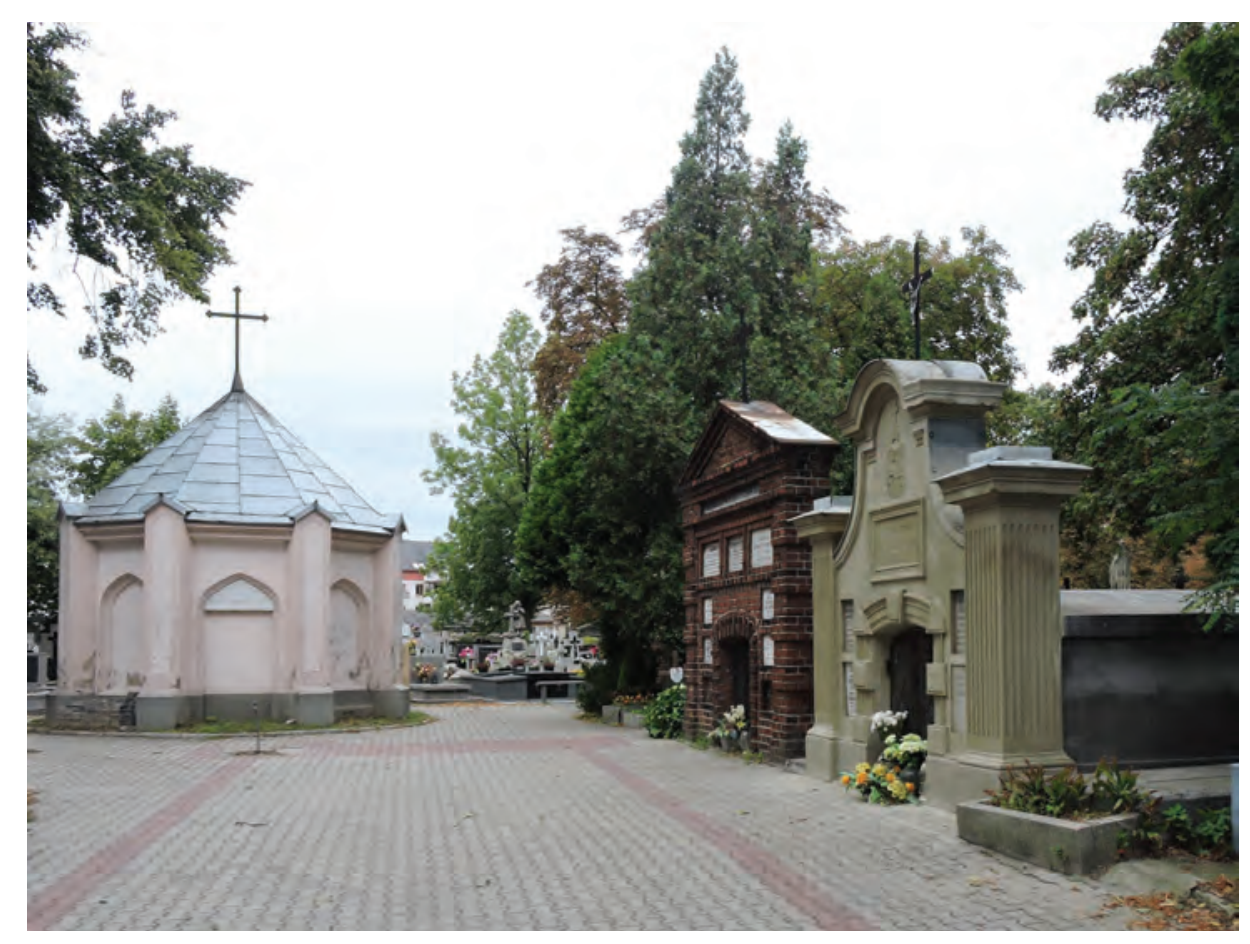

7. Cmentarz katolicki w Kaliszu - fragment. Fot. K. Stefański, 2017

Cmentarz ten ma swój plan z podziałami na kwatery, ma kontrolę grobów, tak, że w lat nawet kilkanaście łatwo będzie odszukać gdzie leżą zwłoki, kontrola bowiem wykazuje kwatery, szeregi i numera. Rozpoczęte w roku zeszłym przebudowanie domu grobowych, w r. b. kontynuuje się energicznie. Stary domek, zwalony, nowy i piękny wzniesiony, obok niego ma stanąć gustowna kaplica grobowa [...].

To zestawienie dwóch spojrzeń na cmentarz - estetyczno-rozpoetyzowanego i utylitarnego - może się wydawać dziwne, ale nie jest odosobnione. Stanisław Rosiek w swojej pracy o postrzeganiu zwłok Mickiewicza zauważa, że patrzący na martwego wieszcza świadek potrafi dostrzec w nich jednocześnie „niewysłowione (duchowe) piękno i medyczny przypadek - lektura fizjologiczna, nie wyklucza estetycznej” ${ }^{18}$. Na łamach „Kaliszanina” teksty estetyzujące rzeczywistość (egzaltowane zachwyty nad pięknem kaliskiego parku) sąsiadują z notkami o występku (dzieciobójstwo ze zwłokami wrzuconymi do kloaki), nędzy, okrucieństwie (męczenie zwierząt) czy prozaicznych uciążliwościach codzienności. Może to sprawiać wrażenie, jakby próby estetyzacji świata ponosiły klęskę, jakby spod fantazji o pięknym

18 Rosiek 1997, s. 147. 


\section{TECHNE \\ T E X N H \\ SERIA NOWA

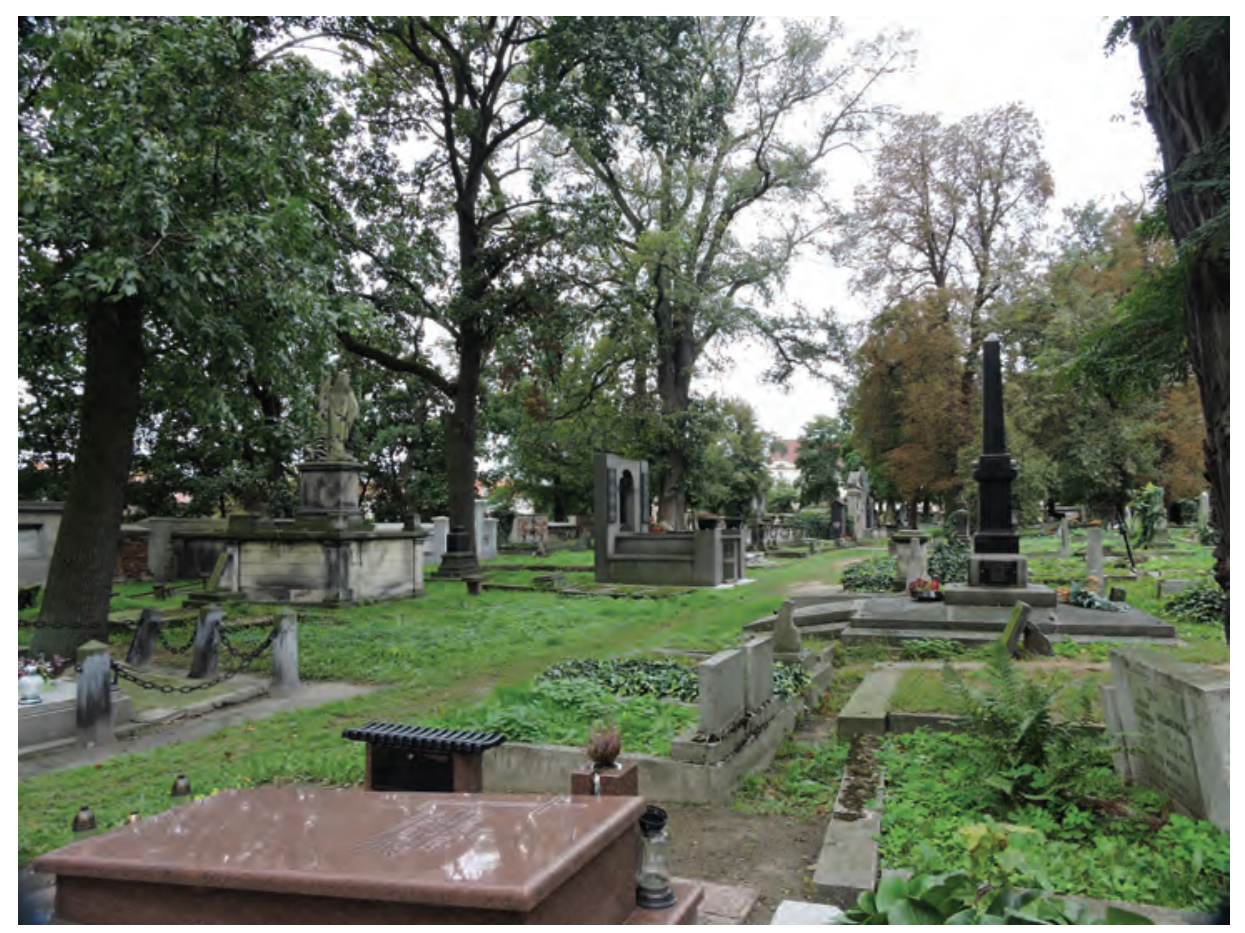

8. Cmentarz ewangelicki w Kaliszu - widok ogólny. Fot. K. Stefański, 2017

świecie przebijała, często opisana niezwykle dosadnie, niepoetycka rzeczywistość. Czy jednak nie był to równouprawniony dwugłos, w którym nie widziano tak rażącej nas dziś sprzeczności?

Urodę cmentarzy dostrzega również odwiedzający miasto były mieszkaniec (1871):

Od lat kilkunastu wiele się tu zmieniło, liczne rzędy nowych przybyło mogił - obok kaplic i bogatych pomników, skromnie wsadzony krzyżyk z napisem niepewną skreślony ręką „Tu leży etc.” wśród gęstych drzew i krzewów różnobarwnych - cichy nieśmiertelnik - symbol nieśmiertelnej duszy człowieka, skromną główkę wychyla, wszystko to, choć w siedlisku umarłych, miłe robi wrażenie dla oka ${ }^{19}$.

Również i tu rodzi się refleksja o nieuniknionym losie: Nie sądzę, aby znalazt się ktokolwiek na którem by widok cmentarza nie zrobił poważnego wrażenia. Ta poważna grobowa cisza mimo woli wskazuje i straszy nas przyszłością ${ }^{20}$. Zdaniem autora cmentarz odzwierciedla relacje społeczne: $Z$ samego widoku cmentarza można

19 Kaliszanin 1871, NR 66.

20 Kaliszanin 1871, NR 62. 


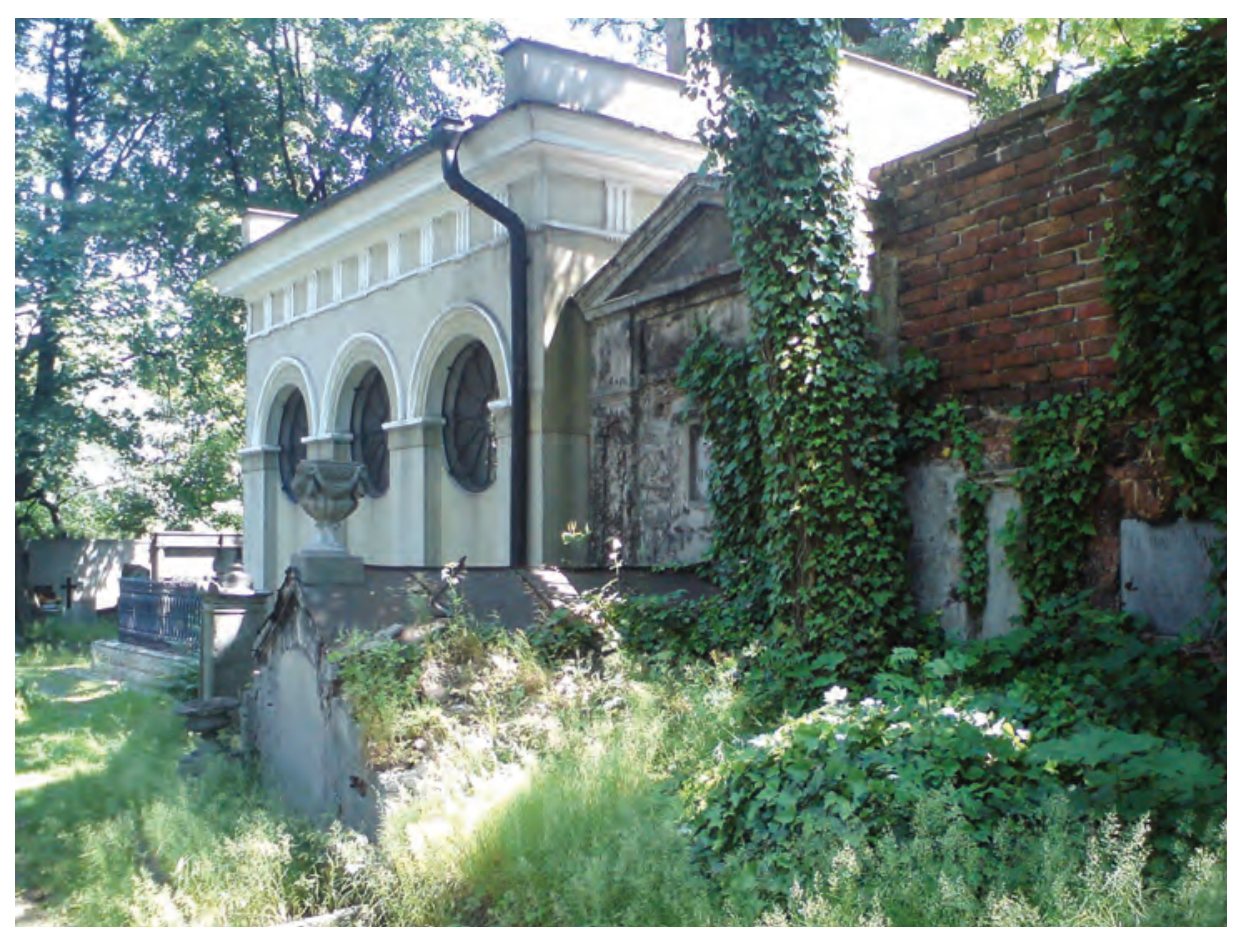

9. Cmentarz ewangelicki w Kaliszu - fragment. Fot. M. Błachowicz, 2011

bez watpienia powziać pewien rys charakteryzujący to kótko społeczeństwa, które w tem miejscu składa ciała swych rodziców, krewnych i przyjaciót ${ }^{21}$. Myśl o widocznej nierówności społecznej wyrażona jest w „Kaliszaninie” (1888): żyjący i do królestwa zmarłych przenieśli walkę o byt, w której zwycięzcami pozostaną ci jedynie, których stać na sarkofagi lub kamienne pomniki² ${ }^{22}$ Przypomnijmy jeszcze raz pochwałę cmentarza ewangelickiego (1871), jakże inną od rzeczywistości cmentarza katolickiego: Dostaje się więc i ubogim to co gdzie indziej maja szczątki tylko bogatych: dostaje się ciche i rzewne słowo pamięci, które do żywych przemawia zielenia murawy i wonia kwiatów [...] $]^{23}$. W „Powieści z Nekropolis”, jakby przeciwstawiając się rzeczywistości, w której sprawiedliwości nie ma nawet po śmierci, Adam Chodyński przedstawia cmentarz w „G” (1888). Trudno powiedzieć, czy jest to opis rzeczywistej nekropolii, czy fantazja autora. W „Ustroniu” (bo tak nazywa się ten cmentarz) nawet biedny, posiada grób z kamienną płytą, a ich likwidacja i przekopywanie jest zakazane $^{24}$. Łatwo tu dopatrzyć się przekonania, że trwałość i opieka nad grobem

\footnotetext{
21 Ibidem.

22 KaLisZanin 1884, NR 73.

23 KalisZanin 1871, NR 45.

24 KalisZanin 1888, NR 13.
} 
nie powinny być przywilejem ludzi bogatych. Według Michela Vovelle’a w fantazjach XIX wieku śmierć ubogiego jest „złą śmiercią” świadczącą o okrucieństwie ciężkich czasów dzikiego kapitalizmu ${ }^{25}$.

Adam Chodyński pisze (1888):

Nędzarz umarł; nie pochowano go w złotem obijanych trumnach, nie obwito ciała jego w jedwabie, nie szły za jego pogrzebem żadne bractwa pobożne, nikt nie mdlał, nikt nie płakał, nie niesiono pochodni, nie grała muzyka, mów pochwalno-pogrzebowych nad jego grobem nie miał żaden kaznodzieja, nie wystawiono mu żadnego nagrobka z marmuru, bo to był nędzarz. Dla niego trumnę stanowiły cztery od wozu deski z litości przez kmiecia dane - całunem była mu licha gruba koszula i zdarta od ciężkiej pracy siermięga; za jego pogrzebem szło dwoje żebraków [...] ksiądz pokropił trumnę przed kościołem, grabarz ją wsunął do dołu, żebracy Zdrowaś i wieczny odpoczynek zmówili; zrobiono mogiłę [... $]^{26}$.

Opisy niewyobrażalnego ubóstwa i cierpień biedaków niejednokrotnie przytaczane są na łamach „Kaliszanina”. Wspomniany cmentarz w „G” jest ciekawy jeszcze z innego względu. Bogaty cudzoziemiec urządził kwaterę na pochówki ludzi innej wiary i narodowości - „Cudzoziemskie ustronie”. Na tej nekropolii, tak jak na cmentarzach w Kaliszu, główną rolę odgrywa przyroda (1888):

O, jakże te miejsca przejmują duszę jakąś miłą rzewną tęsknotą! Co za urocza półcisza! [...] liść o liść potrąca, wierzchołki wysokich topoli szumią tajemniczo; kiedy niekiedy ozwie się słowik w krzakach bzowych, zaszczebiocze zięba na akacji, szczygieł poruszy gałązki berberysu, a wonny wiatr wciąż kołysze liśćmi kasztanów i brzóz, co tu ocieniają mogiły cudzoziemskich dzieci.

Charakterystyczne, że w opisach brak wypowiedzi na temat pomników. Są co najwyżej bogate, ale niewarte uwagi, wzruszeń dostarczają zwykłe mogiły przystrojone kwiatami. To przyroda i melancholijny charakter miejsca są głównym źródłem piękna nekropolii. Cmentarz w „G” przypomina Kalisz pod jeszcze jednym względem (1888): miejsce to ma dwa przedziały; jeden na cmentarzu katolickim - drugi na ewangelickim: ten mur, w którym jest furta do przechodzenia z obu cmentarzy, rozłacza je od siebie. Założyciel tych ustroni był katolikiem, nie przepomniał jednakże o ludziach obcego wyznania ${ }^{27}$. Podobnie w Kaliszu - mieszkańcy miasta koegzystują ze sobą również po śmierci: trzy cmentarze chrześcijańskie sąsiadują ze sobą - obok katolickiego i ewangelickiego, prawosławny. W przypadku nekropolii

\footnotetext{
25 VOVELLE 2008, s. 579.

26 KalisZanin 1888, NR 10.

27 KalisZanin 1888, NR 13.
} 
$25 \mid \begin{gathered}\text { TECHNE } \\ \text { TEX N H } \\ \text { SERIA NOWA }\end{gathered}$

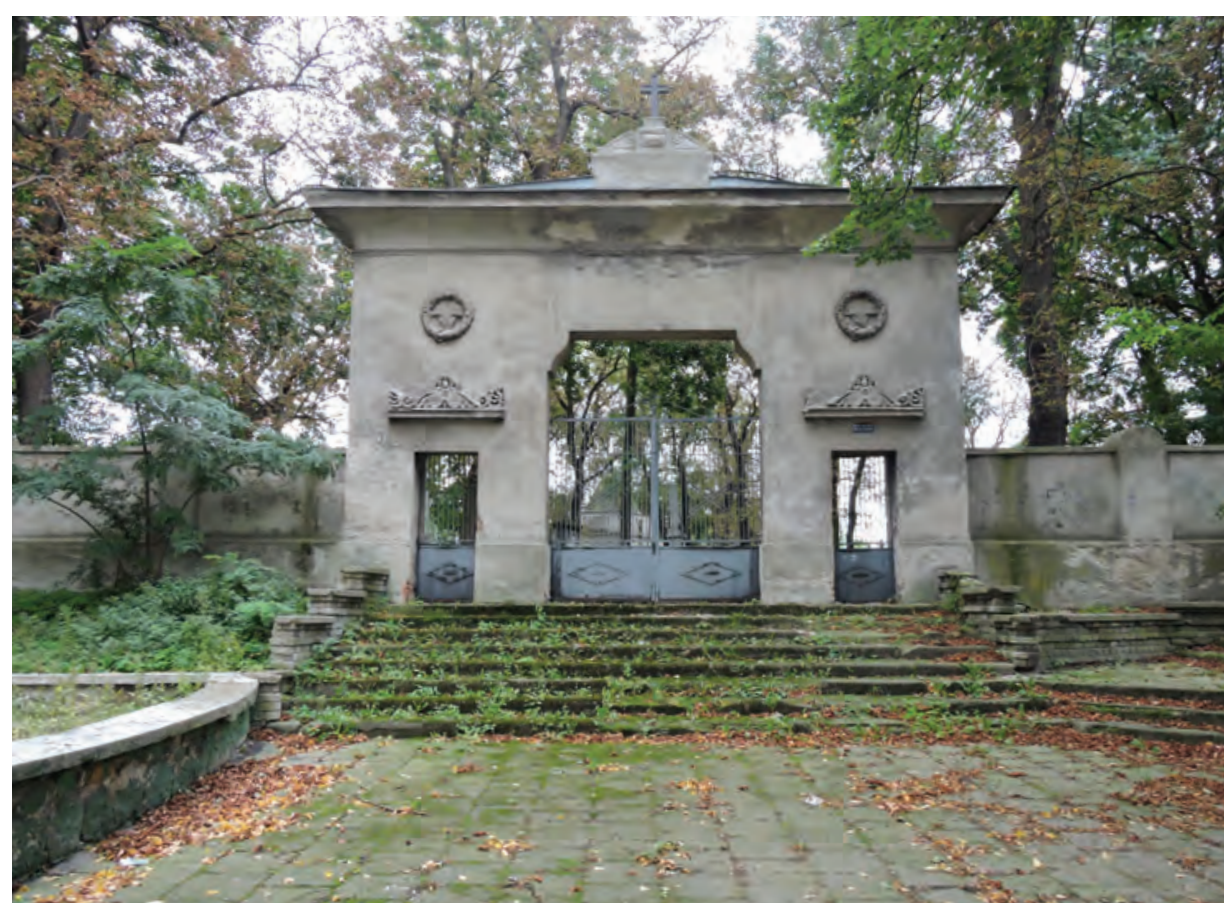

10. Cmentarz prawosławny w Kaliszu - brama wejściowa. Fot. K. Stefański, 2017

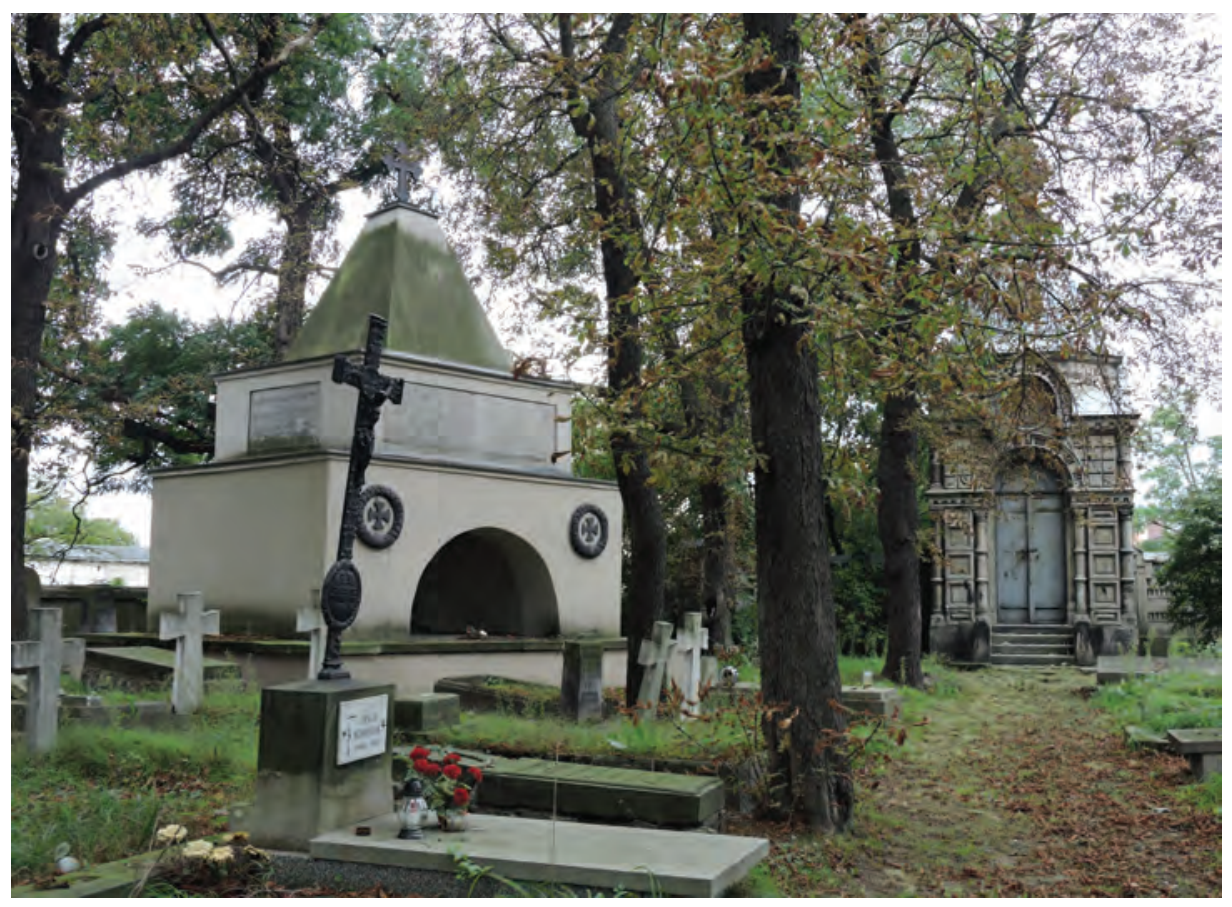

11. Cmentarz prawosławny w Kaliszu - fragment. Fot. K. Stefański, 2017 
ewangelickiej i katolickiej sąsiedztwo „za murem” pozwoliło rodzinom katolicko-protestanckim chować zmarłych krewnych obojga wyznań we wspólnym grobowcu na granicy cmentarzy. A jednak nie udało się zrealizować pomysłu Chodyńskiego, czyli wybić furtki łączącej nekropolie. Przyczyny niepowodzenia nie są znane. Historyk swoje propozycje zmian na cmentarzu przedstawił w artykule Kilka myśli o cmentarzu w Kaliszu ${ }^{28}$ (1870).

„Ustronie”, jak i cmentarz ewangelicki, są odległe od rzeczywistości Cmentarza Miejskiego w Kaliszu w drugiej połowie XIX wieku. Tekst ukazujący piękno nekropolii protestanckiej powstał m.in. dla zainspirowania zarządu cmentarza katolickiego (1871):

Czyby nie można było i na katolickim cmentarzu przyjąć podobnego środka do upiększania cmentarza, do zaprowadzenia na nim radykalnego ładu, bo jakkolwiek od roku zeszłego uczynił on znaczny krok ku postępowi, dzięki staraniom p. Kindlera, jednakże porządek ten należy utrwalić i zmienić w stałą zasadę, ani od zmian członków dozoru, ani zmian grobowych niezawisłą ${ }^{29}$.

Rok później „Kaliszanin” drukuje nietypowy, dla stonowanej z reguły w opiniach gazety, ostry tekst (1872):

Jeśli kto, to przynajmniej na ofiarowanie palmy pierwszeństwa za niedbalstwo, zasługuje dozór katolickiego cmentarza w Kaliszu. Miejsce to tak poważne, ze wszech względów mające za sobą prawo do rozciągania troskliwej nad niem pieczy - przedstawia smutny widok zaniedbania zwłaszcza w porze niepogód, jesieni i wiosny. Czego tu nie zrobi prywatna opieka, lub grosz pojedynczy, tego też nie uczyni i dozór cmentarny, że zaś drogi i postaranie się o odciek wód przez wybicie rowów nie leży w obrębie prywatnej troskliwości, zatem owe drogi na cmentarzu kaliskim dają wstrętny widok śmietnika. Nie ma miejsca, nie ma ścieżynki, gdzieby można było przejść lub stanąć suchą nogą. Wszędzie woda, kałuże, wilgoć i błoto po pas. Taki stan cmentarza nie odpowiada zaprawdę warunkom naszego miasta, nie odpowiada wreszcie ani względom religijnym, ani społecznym, ani hygenicznym ${ }^{30}$.

W świetle prasy stan nekropolii nie poprawi się przez cały badany okres.

Zadziwiającą rzeczą jest fakt, że cmentarz nie jest tu spostrzegany jako miejsce, które nocą z przestrzeni poświęconej pamięci zmarłych staje się przestrzenią wymykającą się racjonalnemu postrzeganiu. Przestrzenią groźną i mroczną ze

28 Kaliszanin 1870, NR 27-29.

29 KalisZanin 1871, NR 45.

30 KalisZanin 1872, NR 22. 
względu na obecność duchów. Wątek ten nie był jednak zupełnie pomijany. W marcu 1884 roku reklamowa grafika z „Kaliszanina” autorstwa A. (imię nieznane) Epstaina, „powszechnie znanego nadwornego prestidigitatora, magnetyzera i spirytysty profesora", kusiła widowiskiem z udziałem duchów ${ }^{31}$. „Kaliszanin” opublikował zresztą umiarkowanie krytyczny tekst poświęcony „spirytyzmowi i hypnotyzmowi"32, przyznając naukowy charakter temu ostatniemu. Temat musiał być dobrze znany, skoro nie uznano za potrzebne tłumaczyć czytelnikom tych pojęć. Pominięcie nekropolii jako miejsca bytowania istot nadprzyrodzonych nie dziwi w przypadku informacji prasowych. Brak jej w ciekawostkach, brak eksploracji tematu w kaliskiej twórczości poetyckiej i literackiej.

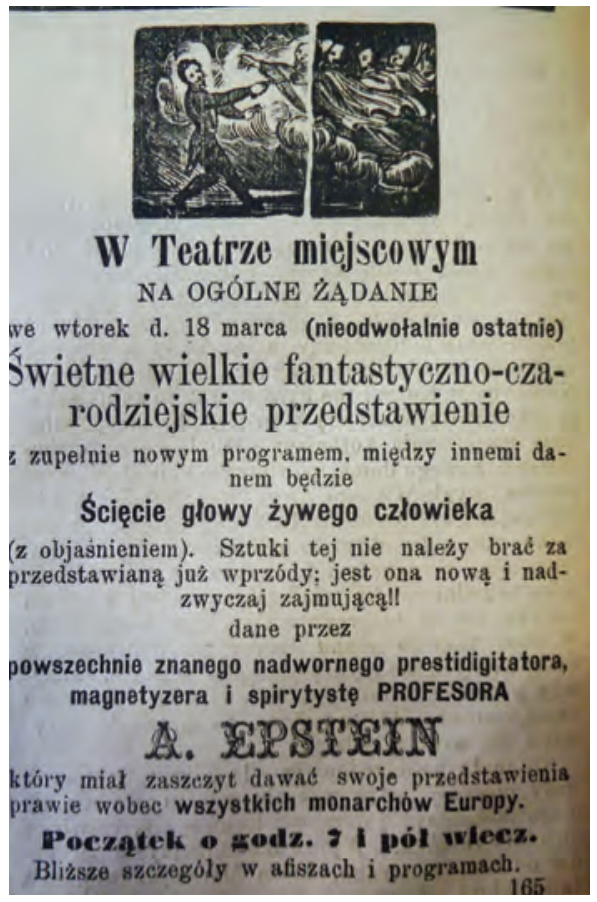

12. Anons reklamowy spirytysty $A$. Epsteina. „Kaliszanin" 1884, nr 23, s. 4 i powiększenie grafiki reklamowej

A przecież duchami wypełniona była niedawna twórczość romantyków. Czyż dzisiejszy czytelnik sięgając po Powieści $z$ nekropolis (1888) Chodyńskiego, nie oczekuje opowiadania grozy? Zamiast tego otrzymujemy dydaktyczną powiastkę o śmierci. Nocne cmentarze i ich widziadła nie goszczą w twórczości zafascynowanego śmiercią pisarza i poety. Czy milczenie to wiąże się z przekonaniami religijnymi, czy z pozytywistycznym racjonalizmem? A może widziano w takim ujęciu coś niestosownego? Groza i fantastyka w źródłach kaliskich pojawi się zupełnie gdzie indziej - w spojrzeniu żywych na szczątki wydobyte $\mathrm{z}$ grobu.

\section{Czym lub kim jest trup? Co dzieje się z duszą?}

Wierzy się powszechnie w pozaziemską egzystencję, duszę trwającą po śmierci. Pewien anonimowy autor zwraca uwagę (1889), że błędne jest określenie „dusze zmarłe”, gdyż dusze nie umierają, a jeśli się mówi lub pisze za „dusze zmarłych” to tylko jest skróceniem „dusze ludzi zmartych”33. Zacznijmy od tego, co pozostało na

\footnotetext{
31 KalisZanin 1884, NR 23.

32 KalisZanin 1892, NR 47.

33 KalisZanin 1889, NR 87.
} 
Ziemi - od trupa złożonego do grobu. Zmarli to osoby, których ciała już w łonie ziemi a duchy odpoczywaja w wieczności (1871) ${ }^{34}$. Chodyński zauważa (1891), że człowiek:

Z istoty, która potęgą przymiotów ducha zda się, że głową niebios sięgała; z istoty tkliwej, kochającej, w której wirowało żądz, pragnień i uczuć tysiące; która umiała cierpieć, poddawać się losom i z nimi walczyć, poświęcać się, być dobrą lub złą, $[\ldots]$ - staje się naraz przedmiot martwy, widokiem swym przestraszając ${ }^{35}$.

Spojrzenie, że trup jest rzeczą, wzmocnione zostaje aspektem medycznym - gnijące szczątki są źródłem groźnych chorób. W 1882 roku z tych właśnie względów „Kaliszanin” zaangażuje się w kwestię zamknięcia cmentarzy przy Rogatce:

[...] woda omywająca trupy spływa do miasta i wiatry wiejące prawie zawsze z tej strony wszystkie wyziewy wnoszą do Kalisza. Dla kogo nie jest obcem rozkład trupa, kto ma pojęcie o wytwarzaniu się w czasie gnicia jadu trupiego czyli gnilnego i innych związków, kto zna warunki życia miazmatów i mikroskopijnych organizmów ten nie postawi swego weto ${ }^{36}$.

Echem wiedzy o tych procesach gnilnych jest zapewne nazwanie cmentarza „smętnym laboratorium śmierci" $(1884)^{37}$.

Od antropomorfizacji zwłok nie można się jednak uwolnić - zwłoki „śpią”, „oczekują" zmartwychwstania i połączenia z nieśmiertelną duszą. Adam Chodyński pisze:

Chrześcijanie, opierając się na dogmacie zmartwychwstania, a więc śmierci ciała nie uważając za jego wieczne zniszczenie, lecz tylko za sen i spoczynek w Bogu, miejscom pochowu zmarłych dali odpowiednią nazwę z greckiego Koimeterion, która przeszła do łaciny w dźwięku „coemeterium”, a z tej znów w języku naszem zmieniła się w cmentarz. Wyraz ten znaczy sypialnię, przybytek spoczynku ${ }^{38}$.

Ciało oczekuje dnia zmartwychwstania: przyjdzie niebios wiosna nieśmiertelna / Człowiek odżyje pod natchnieniem wiary, / Wskrzesi go Bóstwa potęga wszechdzielna; / I piękność wieczna odzieje go w ciało, / W którem nic ze skaz ziemi nie zostało! $(1884)^{39}$. Trup nie tylko po ludzku „śpi”, ale po ludzku jest „mieszkańcem”

\footnotetext{
34 Kaliszanin 1871, NR 87.

KALISZANin 1891, NR 65.

36 KalisZanin 1882, NR 20.

37 Kaliszanin 1884, NR 10.

38 Kaliszanin 1891, NR 69.

39 KalisZanin 1884, NR 65.
} 
grobu i cmentarza. Nekropolia nie jest tylko składnicą szczątków, ale staje się miastem czy państwem umarłych: Nic go już nie zbudzi z tej senności koniecznej; nieczułym jest na głos miłości i obojętnym na wołanie przyjaźni. Umarł; przez śmierć wytraccony z grona żywych, zajmie skromny zakatek $w$ grodzie milczacym. Nowy to obywatel Nekropolji [...] (1891) ${ }^{40}$.

Interesujące jest to, że redaktorzy „Kaliszanina” pewną uwagę poświęcają alternatywnemu postępowaniu ze zwłokami (1886): we Włoszech [...] istnieje przeszło 60 stowarzyszeń zwolenników palenia zwłok, a w 1885 r. w samym Rzymie odbyto przeszło sto kremacji ${ }^{41}$. W 1891 roku gazeta informuje, że pali się zwłoki w Japonii, gdzie na 34437 zmarłych skremowano 11023 osoby $^{42}$. W 1892 roku donosi, że palenie ciał zostało w Danji przez władze dozwolone. Krematorjum wzniesione w Kopenhadze przed lat sześciu będzie oddane wkrótce do użytku publicznego. Rada miejska Lyonu uchwaliła 270000 fr. na wybudowanie krematorium na miejscowy cmentarzu ${ }^{43}$. Brak jest odniesienia się do strony etycznej zagadnienia, mimo że przeciwnikiem kremacji był Kościół katolicki, widzący w niej odrodzenie pogaństwa i zaprzeczenie dogmatowi o zmartwychwstaniu. Zapewne z perspektywy Kalisza kremacja była zbyt odległą nowinką, aby rozpatrywać ją w kategoriach innych niż egzotyczna ciekawostka. Ten sam charakter miały notki (1888) o turyńskim profesorze fizyki i chemii, niejakim Angelo Mottcie, który trzydzieści lat poświęcił metalizacji zwłok ludzkich za pomoca wynalezionej przez siebie manipulacji chemicznej, majacej na celu zniszczenie organicznej substancji trupa i zastąienie jej w zupetności przez metal ${ }^{44}$. Chyba nieprzypadkowo właśnie w Dzień Zaduszny (1889) pojawił się artykulik o tym, że niejakim dr Copper z Pitsburga wynalazł:

[...] proces, którym proponuje zastąpić balsamowanie i palenie ciał. Podaje on mianowicie ciała zmarłych ciśnieniu hydraulicznemu, obracając w ten sposób ciała w kamień, przypominający marmur. [...] Dr Copper przedstawił między innymi niewielkich rozmiarów krzyż, na pierwszy rzut oka zdawałoby się marmurowy, który jednak stanowił ciało dziecka, poddane ciśnieniu ${ }^{45}$.

Czyżby szukano metody mającej zapobiec potworności grobowego rozkładu i w ten sposób wyrugować najmniej estetyczną stronę śmierci? Z drugiej strony redaktorzy „Kaliszanina” bez entuzjazmu przyjęli trumnę „higieniczną” niejakiego Leopolda Repsa z Warszawy (1890). Wykonano ją z tajemniczego stopu metalu:

\footnotetext{
KALisZanin 1891, NR 65.

KALiSZANin 1886, NR 83.

KaLisZanin 1891, NR 22.

KALISZANIN 1892, NR 35.

KalisZanin 1888, NR 48.

45 KalisZanin 1888, Nr 87.
} 
nieboszczyk po umieszczeniu $w$ trumnie tego rodzaju, po wypompowaniu z niej powietrza i hermetycznem zamknięciu, przez dlugi przeciagg czasu przechowywać się ma bez widocznego rozkładu ${ }^{46}$. Redaktor konstatuje z nutą ironii, że niedługo wynalezione zostaną „, higieniczne armaty”.

Charakterystyczne, że kaliscy autorzy w nikłym stopniu piszą o pozaziemskiej egzystencji, mało tu o szczęśliwości doświadczanej przez dusze, jeszcze mniej o ewentualnych mękach piekielnych. To ostatnie spostrzeżenie zgadzać się może z uwagą Philippa Ariès, że człowiek XIX wieku nie wierzy już w piekło - „jest to dogmat, o którym uczył się w katechizmie, ale który nie wiąże się z jego uczuciowością" ${ }^{37}$. U Chodyńskiego piekło nie pojawia się - jest tylko sąd: Przyjdzie kiedyś czas dla każdego, że musi złożyć wielki z życia swego rachunek; tam będziemy tylko za samych siebie odpowiadać, a tyle tylko ciążyć będą na nas winy cudze, o ileśmy dawali innym do nich popęd, lub też o ileśmy na nie z obojętnościa spoglądali $(1888)^{48}$. Jego zdaniem ludzkie zegary liczą tylko godziny dla żyjacych, - umarli ich nie mają; dla nich uderza jedynie olbrzymi zegar wieczności, którego chwilki są dłuższe jak wszelkie wieki ziemi ${ }^{49}$. W tekście poświęconym młodziutkiej Aleksandrze Tahn $(1879)^{50}$ zmarła jest „szczęśliwa jak anioł w niebie” (Narcyza Żmichowska). Chodyński, który był jej wujem, wyobraża sobie, że zmarła spoczywa na łożu (wiecznej łożnicy) i śniąc doświadcza szczęśliwości - „i będzie ci spokojnie, słodko i nieprzespanie [...]”. Wizja „łoża śmierci” z młodą niewinną kobietą to fantazja niezwykle atrakcyjna dla epoki, częsty motyw dziewiętnastowiecznej rzeźby nagrobkowej ${ }^{51}$. „Spokojowi mogiły” - stanowi snu, w którym znalazła się Aleksandra, przeciwstawione jest trudne ziemskie życie: „tu śród ludzi zanadto jeszcze trosk i cierpienia [...] tu wszystko jest smutne”. Śmierć jest wyzwoleniem od wszystkich trudów życia: „Bo tu od walki od zniechęcenia / Prędko serce się utrudzi” (Narcyza Żmichowska). Jedyna zmiana dotyczy pór roku, nie mają one wpływu na stan dziewczyny, zmieniając jedynie scenerię łoża - Zima zawiała śniegiem Twa łożnice - wieczną; Wiosna porzuci na niej kwiaty, które zasieje ręka życzliwa i trawę, której Bóg wyróść tam każe. I będzie Ci spokojnie, słodko i nieprzespanie - zarówno w maju jak w grudniu ${ }^{52}$. Zdaniem Michela Vovelle’a śmierć jako sen jest jednym z motywów przewodnich obecnych w kulturze Zachodu od końca XVIII wieku ${ }^{53}$. Odnosi się wrażenie, że dla kaliskich autorów metafora snu

\footnotetext{
46 Kaliszanin 1890, NR 19.

47 ARIES 1989, s. 464

48 KalisZanin 1888, NR 6.

49 KalisZanin 1888, NR 13.

50 Ibidem, KALISZANin 1879, NR 92. Tekst opublikowany również: CHODYŃSKi 2010, s. 104-105. Autor obok tekstu własnego publikuje fragmenty utworu Narcyzy Żmichowskiej.

51 VOVELle 2008, s. 587.

52 KalisZanin 1879, NR 92. Tekst opublikowany również w: CHODYŃSKi 2010, s. 104-105.

53 VOVELle 2008, s. 485.
} 


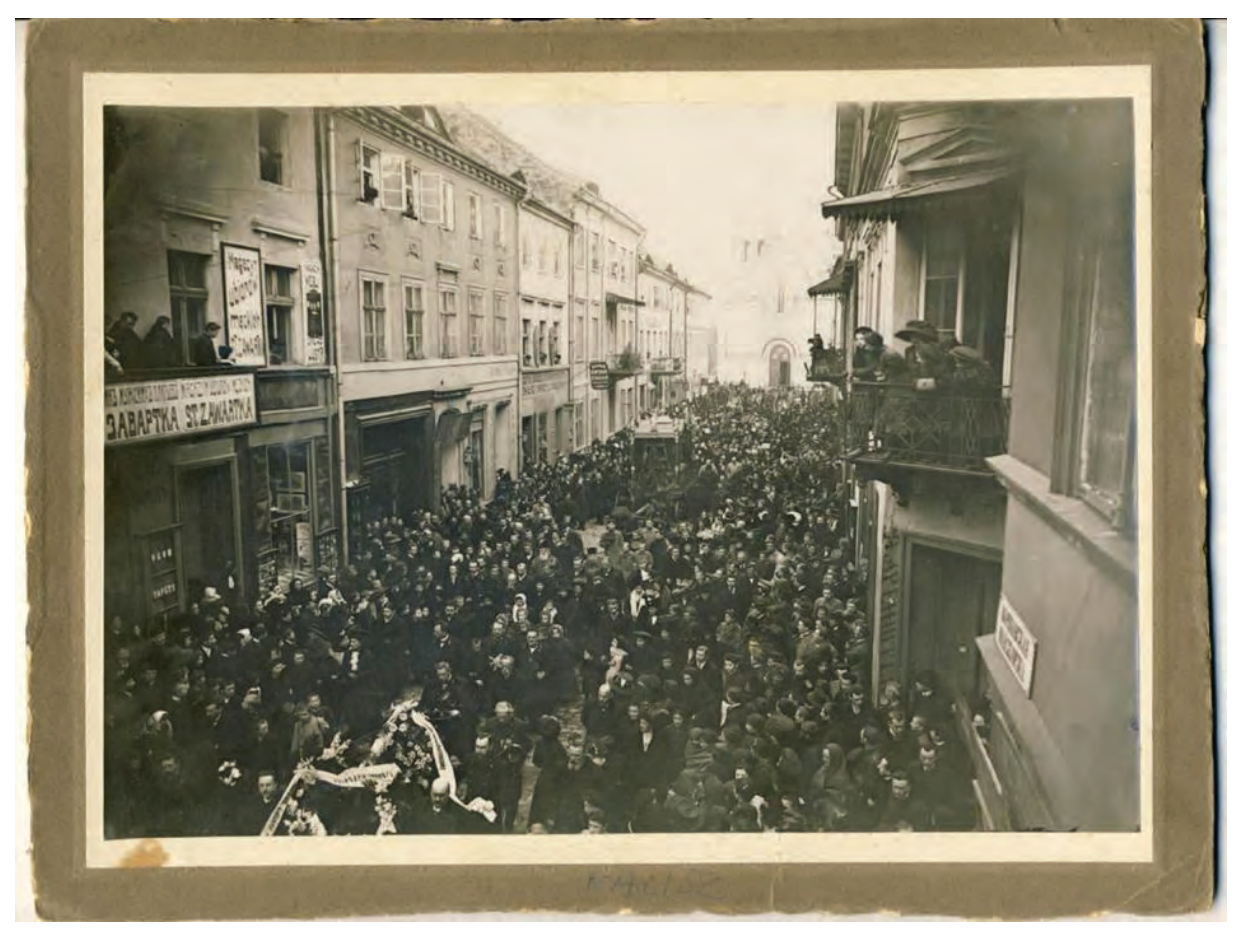

13. Pogrzeb nieznanej osobistości wyznania prawosławnego w Kaliszu - przełom XIX i XX wieku Fot. ze zbiorów Książnicy Pedagogicznej im. A. Parczewskiego w Kaliszu

jest o wiele bliższa niż inne wyobrażenia. We wspomnianym utworze poświęconym Aleksandrze Tahn nie ma nic o duszy, choć jest o woli Bożej. Brak więc dychotomii, w której ciało oczekuje zmartwychwstania w grobie, a dusza jest w zaświatach. Jeśli „to”, co jest w „wieczystej łożnicy”, nie jest trupem, a pogrążoną we śnie i szczęśliwą Aleksandrą, to jak jednocześnie pisać o Aleksandrze - duszy egzystującej w zaświatach? Trudno podejrzewać religijnego Chodyńskiego o zaprzeczanie dogmatom, jednak nawet jemu jakby łatwiej jest pisać o pośmiertnej egzystencji, korzystając z metafory snu. Czyżby wykształconym ludziom XIX wieku coraz trudniej było wyobrazić sobie życie pozagrobowe? Nie znaczy to, że je odrzucają. Wręcz przeciwnie, żarliwie w nie wierzą. W nekrologu siedemnastoletniej Anny Daragan (1889) anonimowy autor pociesza: Jeśli cokolwiek przynieść może pocieche w podobnym smutku, [...] to chyba myśl o wieczności i nadzieja, że tam gdzieś w pozagrobowym świecie spotkają się znowu duchy czyste i nie rozłączą się już nigdy ${ }^{54}$. Zdaniem Michela Vovelle’a ulatujaca dusza i pośmiertne spotkanie $w$ zaświatach to toposy zbanalizowane i spopularyzowane ( $w$ XIX wieku) w stopniu niespotykanym, być może dlatego, że odpowiadaja nowemu typowi indywidualnej i rodzinnej uczuciowości $i^{55}$.

54 Kaliszanin 1889, NR 41.

55 Vovelle 2008, s. 485. 
Wtóruje mu Philippe Ariès: „w wieku XIX wszyscy zdają się wierzyć w kontynuację ludzkich związków uczuciowych po śmierci" ${ }^{36}$. W wierszu Chodyńskiego z cyklu Nenufary (1888) pojawia się przekonanie o przyszłym spotkaniu: O tam, daleko! gdzie milionami / Usiana w gwiazdy jest „Mleczna droga” - / Spotka się z kiedyś z wami, / Dusza znękana nieboga. / Chrystus powiedzial: U Ojca mego / w Miejsc taka wielość w jego dziedzinie". / Ja też dla ducha bardzo tęsknego / Czekam miejsca $w$ tej krainie ${ }^{57}$. Podobnie w wierszu Melancholia (1872), gdzie ci, których nie ma, odnajdą się Gdzie duchów kraj / Gdzie wieczny maj / Gdzie Bóg jest sam ${ }^{58}$. Nekrolog Anny Daragan zwraca uwagę, że oznaką żalu po zmarłej jest szczera modlitwa, [...] przed Tron Najwyższego o anielstwo dla zmartej59. Zmarli, jak zauważa Chodyński (1886), od nikogo nic już nie pożądaja, prócz tylko modlitwy $i$ wspo$m n i e n^{60}$. Swoje poglądy eschatologiczne Chodyński najpełniej ujawnia w Opowieściach z nekropolis:

[...] tu każdy jest równy, każdy dobry, każdy jednemu i temu samemu co wszyscy podlegający wpływowi - to jest gniciu. Najważniejsza ich połowa - dusza poszła już w świat inny; tu zostały ciała, a tam zaniesiono czyny żywota przed sąd Boga, który też stosownie to do nich wymierzył każdemu, co należało. Śpią wszyscy snem głębokim, dopóki ich kiedyś z niego anioł nie pobudzi - śpią mali i wielcy przy sobie odpoczywają w ciszy najgłębszej, milczeniu i jedności; ustały tu swary żywota, kłótnie, zatargi, jeden drugiemu równy w tej szczególnej republice [...] Tu kraina śmierci, tu równowaga dla ciał zmarłych ${ }^{61}$.

Stefan Giller widzi (1884) w człowieku istotę podlegającą zniszczeniu i przemianie: znoszone zwłoki, które $z$ siebie zrzucit, wracaja do ziemi na przeksztatcenie, na nowy płaszcz cielesny ${ }^{62}$. Kiedy bohaterowie jego opowiadania leżą już w grobach: Przyroda jak gdyby się nic nie stało, nie wyszła ze swego porząku... $i$ w pracowni swej wiecznej czasów i przestrzeni, tworzyła wciąż dalej ze śmierci na nowe życie na nowe śmierci zniszczenie. Grób okrywa ziarno życia oddane ziemi... Zagłady zupełnej we wszechświecie nie ma nigdzie... ${ }^{63}$. Jednak według Gillera człowiek jest czymś więcej niż materia: „Przez śmierć wyzwala się duch do ojczyzny swej nieśmiertelnej na nowe życie, na wieczne...” W świecie żywych pozostaje pamięć:

\footnotetext{
56 ARIEs 1989, s. 462.

57 Kaliszanin 1888, NR 78.

58 ChODYŃSKi 1872, s. 21.

59 KalisZanin 1889, NR 41, s. 2.

60 Kaliszanin 1886, NR 66, s. 1.

61 Ibidem, s. 2.

62 Kaliszanin 1884, NR 99, s. 1.

63 Ibidem.
} 
„sama istota $\mathrm{z}$ ducha i zwłok swych rozebrana, przenosi się $\mathrm{w}$ krainę pamięci, do czarodziejskich światów wyobraźni”"

Inny autor (1886) zdając sobie sprawę z powszechności śmierci, używa eufemizmu „znikanie”:

Bywają momenta, których górującym wrażeniem jest śmierć. Znikanie wówczas ludzi głośnych, jako wybitnych przedstawicieli pewnych zasad lub kierunków $\mathrm{w}$ polityce, nauce lub sztuce, słowem w życiu społecznem, znikanie to stanowi fakt dominujący, bo nie każda powstała przez śmierć pustka z równą korzyścią zapełniona być może ${ }^{65}$.

W wierszu Chodyńskiego Nenja ${ }^{66}$ (1872) podmiot liryczny szuka, ale nie znajduje zmarłej na cmentarzu: Gdzie szemrza białe brzozy płaczace; / tam grób cię w swoim uścisku trzyma, / I tam cię szukam - lecz i tam niema! ${ }^{67}$. I znów mamy pozorną sprzeczność - grób trzyma w uścisku zmarłą, a jej tam nie ma. Podobnie młodzieniec - rzemieślnik, klęczy przed grobem matki i zwraca się do niej (1871): O matko moja męczenniczko za życia, czyż $i$ w grobie nie zaznasz spoczynku?... Cześć twym popiołom święta matko moja, tyśs w walce z życiem zdobyła sobie wieniec męczeński...duch twój pośród aniołów, a prochy pozostałe w ziemi nienawistny gwałci człowiek! $!^{68}$. Bohater zdaje sobie sprawę, że w grobie są tylko "prochy”, ale czuje potrzebę przemawiania do zmarłej, a po modlitwie przytula się do grobu, jakby chciał być „bliżej” niej.

Podobnie czuje matka podpatrzona przez „Kaliszanina” w 1891 roku: $W$ dzień wigilijny [...] widzieliśmy na cmentarzu kobiete biedna, zatykająca gaiczek na mogiłce dziecięcej. Zapaliła na nim kilka świeczek, objęła rękoma ubogi grobek i płacząc rzekła: „Przynoszę ci gwiazdkę moja miła dziecino; rok temu patrząc na gaiczek, klaskałeś z radości w raczki69. Philippe Ariès zauważa, że w wieku XIX „cmentarz publiczny skupi na sobie całą miłość i cześć dla zmarłych”70. To, co być może wzrusza i wzruszało w tych postaciach, to ich osamotnienie - zdaniem Michella Vovelle’a „główną cechą śmierci biedaka, stawiającego go niejako poza społecznym porządkiem, jest jej samotność" ${ }^{71}$. Tu samotność zmarłych przeniesiona jest na samotność żywych.

64 Ibidem.

65 Kaliszanin 1886, Nr 70, s. 2.

66 Nenia - pieśń żałobna śpiewana w starożytnym Rzymie podczas pogrzebu i na stypie.

67 ChOdÝnski 1872, s. 32.

68 Kaliszanin 1871, NR 66.

69 Kaliszanin 1891, Nr 102.

70 ARIES 1989, s. 513.

71 Vovelle 2008. s. 580. 
W opowieściach tych śmierć jest często wybawieniem od trudnego życia, a zmarły jest nadal kochany i pamiętany przez żywych. Cztery lata, jak z woli Boga / Rzuciłaś ziemską cierpień koronę / Lecz w mej pamięci żyjesz wciąż droga / I cnoty Twoje tak niezamglone ${ }^{72}$ - pisał w kolejną rocznicę zgonu Jadwigi Jałowieckiej mężczyzna podpisany jako Ant. Sar. (Antoni Sarnecki?) - zapewne narzeczony (1884). Żal po zgonie stłumiony jest wyobrażeniem, że zmarła jednak w jakiś sposób czuwa: Bo ty z za świata ogrzewasz serce, Gdy słabnąć zda się w morzu kłopotów - Ty wspierasz umysł $w$ zwątpień rozterce, Do ciebie zawsze duch mój jest gotów $w^{73}$. Mniej pewności co do przyszłych losów ma autor podpisany „H.W.” (1891), który postrzega świat jako nieprzeniknioną tajemnicę, a uświadomienie sobie niemożności jej zgłębienia ma być przyczyną działalności artystycznej. H.W. zadaje dramatyczne pytanie:

Czy poza grobem znajdziemy odpowiedź, czy są światy wiekuistej harmonii? Co, jak gdzie i kiedy - życie nasze, świat cały, to jeden wielki znak zapytania. Świat drugi, pozagrobowy, w różnych postaciach przedstawia nam poezja. [...] Czterech najgenialniejszych poetów w różnych formach przedstawiło nam światy pozamogilne, lecz gdzie prawda, gdzie rozwiązanie, któreby nam zdołało wystarczyć? Darmo - błąkać się zawsze w ciemnościach to nasze przeznaczenie ${ }^{74}$.

Pesymistyczny ton nieśmiało zapowiada niepokoje „Młodej Polski”.

Wspomniałem już, że kaliscy autorzy zdają się nie dostrzegać w cmentarzu miejsca grozy. Ich wyobraźni nie zaludniają upiory, wampiry, a na cmentarzu nie dzieje się nic mrożącego krew w żyłach. Poza jednym - przypadkami straszliwego pogrzebania żywcem. Nie można zdaje się wyobrazić sobie większej męczarni od tych, jakie musza znosić ofiary pozornej śmierci pogrzebane żywcem i budzace się $z$ letargu $w$ trumnie i w grobie ${ }^{75}$ - donosił w 1884 roku „Kaliszanin”. Gazeta przytacza niepokojące informacje (1880): Gdy otwarto trumnę, zmarły istotnie już nie żyt, wszakże policzki jego byly strasznie podrapane, a rysy jego twarzy, śladami przebytych, okropnych widocznie boleści zmienione ${ }^{76}$. Niejaki dr B. twierdził (1892): Spieszyć się z pochowami, jest to może skazywać wielu żywych na okropny skon w grobie ta epidemia dotyka głownie nerwy a ich czasowe obezwładnienie, miewa wszelkie pozory śmierci rzeczywistej. Gdyby po cholerze rozkopano cmentarze, włosy by nawet wstały na łysych głowach ${ }^{77}$. Jeśli u kaliskich autorów pojawia się cmentarna groza i makabra,

\footnotetext{
KalisZanin 1884, NR 13, s. 4.

Ibidem.

KaLisZanin 1891, NR 87.

KAlisZanin 1884, NR 86.

Kaliszanin 1881, NR 5.

77 Kaliszanin 1892, NR 18.
} 
to bez wątków nadprzyrodzonych. Nawet najbardziej fantastyczna opowieść Chodyńskiego (1892) zawierająca dziecinne (miał wtedy 14 lat!) wspomnienie ekshumowanych w 1846 roku zwłok z kościoła reformatów w Kaliszu, jest uzasadniona dydaktyką obrazu, pouczeniem, że umrzemy wszyscy:

Rzecz to istotnie dziwna, jak jest niweczącą koścista dłoń śmierci! Z owych pięknych strojów, pozostały tylko szmaty i strzępy świadczące o znikomości wszystkiego. Fantastyczny marzyciel mógłby pomówić właścicieli niegdyś owych czaszek, piszczeli i szkieletów, że wykradając się nocą z podziemia, odbywali po świecie wycieczki, tak im się zdarło obuwie i rozleciały jego podeszwy, lub też, że toczyli ze sobą boje, w których doszczętnie porozrywały się ich szaty ${ }^{78}$.

Przypomina to barokowe dance macabre czy opowieści Poego, ale narrator zaraz racjonalizuje. Żyjących szkielety istnieją tylko w głowie „fantastycznego marzyciela”.

Zwłoki spoczywające w grobie nie zawsze są zresztą przerażające. Ciało biskupa Andrzeja Wołłowicza (zm. 1822 r., pochowany w kolegiacie kaliskiej) oglądane przez Chodyńskiego trzydzieści pięć lat od śmierci dostojnika: „było jak najdoskonalej zachowane z wyrazem powagi na spokojnej twarzy, okolonej siwym włosem wychodzącym spod piuski”. ${ }^{79}$ Opis sugeruje, że zmarły wygląda, jakby spał. My raczej będziemy sądzić, że oglądano wyschniętego, zmumifikowanego trupa. O fascynacji, czy wręcz przyjemności z fantazjowania o zmarłych i szkieletach w resztkach kosztownych ubrań, świadczy to, że pisarz do ekshumacji reformackiej wracał kilkakrotnie. W ten sposób Chodyński, niewątpliwie epigon romantyzmu, realizuje słowa Michela Vovelle’a o „frenetycznym romantyzmie, który nie tylko nie unika śmierci i próbuje ją oswoić, lecz znajduje w niej upodobanie i w poszukiwaniu silnych doznań nurza się w jej atmosferze" ${ }^{80}$. Mimo to granica nie zostaje nigdy przekroczona. Uzasadnienie zawsze jest racjonalne: naukowe poznanie przeszłości czy dydaktyczny charakter obrazu. Wszystko, co mogłoby być wynikiem obecności duchów, zdaje się podlegać wytłumaczeniu. Nieznany redaktor „Kaliszanina” tłu$\operatorname{maczy}(1874)$ :

Gazowi fosforowo-wodornemu przypisują chemicy tworzenie się w naturze tak zwanych ogników, albo światełek błędnych, jakie dają się postrzegać w nocy na cmentarzach [...] i w szczególności w miejscach, gdzie gniją istoty organiczne, w skład których, (w szczególności mózgów i kości) wchodzi fosfor. Ogniki te [...] są nadzwyczaj ruchliwe, - to biegną w różnych kierunkach, to się podnoszą, to opadają, to ścigają przechodnia ${ }^{81}$.

\footnotetext{
78 Kaliszanin 1892, NR 8.

79 KalisZanin 1872, Nr 18.

80 Vovelle 2008, s. 556.

81 KalisZanin 1874, NR 55.
} 
Wiara w nadprzyrodzony charakter tych zjawisk jest domeną ludzi niewykształconych: Lud nasz wierzy, że błędne ogniki na cmentarzach, sa to dusze pokutujace, które wychodza z grobów, aby błąkać się po ziemi i albo niepokoić żywych, albo się nimi opiekowaćs2.

Podsumowując znamienne dla drugiej połowy XIX wieku wyobrażenia na temat cmentarzy i zmarłych, trzeba podkreślić, że kaliscy autorzy na ogół nie przekraczają ram wyznaczonych przez chrześcijaństwo, choć nie potrafią obyć się bez antropomorfizacji ciała - trupa. Zdziwienie budzi brak tak wydawałoby się oczywistej fantazji, jaką są duchy i zjawiska nadprzyrodzone w nocnym pejzażu cmentarza. Pominięcie zgoła osobliwe - czy jest w nim ukryty sens, czy jest ono tylko wynikiem małej reprezentatywności źródeł? Sprawę tę zostawiam bez rozstrzygnięcia.

\section{Bibliografia}

\section{Źródła}

Chodyński 1872 - Adam Chodyński, Melancholja. Poezye, Drezno 1872.

Chodyński 2010 - Adam Antoni Chodyński, Spuścizna literacka (Poezye), zebrała i opracowała Danuta Kawalerska, Kalisz 2010.

Kaliszanin 1870, NR 27 - Ad.Ch. [Adam Chodyński], Kilka myśli o cmentarzu w Kaliszu, „Kaliszanin", 1870, $\mathrm{nr} 27$, s. 108.

Kaliszanin 1870, Nr 28 - Ad.Ch. [Adam Chodyński], Kilka myśli o cmentarzu w Kaliszu, „Kaliszanin", 1870, nr 28, s. 112.

Kaliszanin 1870, Nr 29 - Ad.Ch. [Adam Chodyński], Kilka myśli o cmentarzu w Kaliszu, „Kaliszanin", 1870, nr 29, s. 116.

KALISZANIN 1871, Nr 45 - Wiadomości miejscowe i okoliczne, „Kaliszanin”, 1871, nr 45, s. 178.

KalisZANin 1871, NR 62 - Wiadomości miejscowe i okoliczne, „Kaliszanin”, 1871, nr 62, s. 246.

KalisZAnin 1871, Nr 66 - K...rz W...i, [Kazimierz Witkowski?], „Kaliszanin”, 1871, nr 66, s. 262.

KALISZANIN 1871, NR 87 - Wiadomości miejscowe i okoliczne, „Kaliszanin”, 1871, nr 87, s. 345.

KALISZANin 1872, NR 18 - Ad. Ch., [Adam Chodyński], Biskupstwo kujawskie i kujawsko kaliskie przez (...), „Kaliszanin”, 1872, nr 18, s. 71.

KalisZANin 1872, NR 22 - Wiadomości miejscowe i okoliczne, „Kaliszanin”, 1872, nr 22, s. 85

KalisZAnin 1874, NR 55 - D, Ogniki albo światełka btędne, „Kaliszanin”, 1874, nr 55, s. 229.

KALIsZANin 1877, NR 67 - Wiadomości miejscowe i okoliczne, „Kaliszanin”, 1877, nr 67, s. 269.

KAliszanin 1879, NR 92 - Ad., [Adam Chodyński], [Notka o zgonie Aleksandry Tahn], „Kaliszanin", 1879 , nr 92, s. 380 .

82 Ibidem, s. 229. 
KALISZANIN 1881, NR 5 - Wiadomości różne, „Kaliszanin”, 1881, nr 5, s. 19.

KALISZANIN 1882, NR 20 - Wiadomości miejscowe i okoliczne, „Kaliszanin”, 1882, nr 20, s. 77.

KalisZAnin 1884, NR 10 - Z miejsc wiecznego spoczynku, „Kaliszanin”, 1884, nr 10, s. 1.

KAlisZAnin 1884, Nr 13 - Ant. Sar. [Antoni Sarnecki?] Wspomnienie. (W rocznice zgonu ś. p. Jadwigi Jałowieckiej), „Kaliszanin”, 1884, nr 13, s. 4.

Kaliszanin 1884, Nr 23 - Ogłoszenia, „Kaliszanin”, 1884, nr 23, s. 4.

Kaliszanin 1884, NR 48 - Adam Dobrowolski, Korespondencja Kaliszanina, „Kaliszanin”, 1884, nr 48 , s. 3.

Kaliszanin 1884, NR 65 - Ad. Ch., [Adam Chodyński], Przekład z Beatti ego, „Kaliszanin”, 1884, nr 65 , s. 3

KALISZANin 1884, NR 73 - W sprawie cmentarza, „Kaliszanin”, 1884, nr 73, s. 2.

KAlisZanin 1884, Nr 86 - Żywcem pogrzebani, „Kaliszanin”, 1884, nr 86, s. 3.

Kaliszanin 1884, Nr 99 - Stefan z Opatówka [Stefan Giller], Przytulisko i zabranka, powieść i klechda karpacka przez (...), „Kaliszanin”, 1884, nr 99, s. 1.

Kaliszanin 1886, Nr 66 - a., [Adam Chodyński], Zrozpaczeni, „Kaliszanin”, 1886, nr 66, s. 1.

KALISZAnin 1886, NR 70 - Na widnokręgu, „Kaliszanin”, 1886, nr 70, s. 2.

Kaliszanin 1886, NR 83 - 4. - Różne wiadomości, „Kaliszanin”, 1886, nr 83, s. 3-4.

Kaliszanin 1888, Nr 6 - Ad., [Adam Chodyński] „Powieści z Nekropolis przez (...)”, „Kaliszanin”, 1888 , nr 6, s. 1.

Kaliszanin 1888, Nr 10 - Ad., [Adam Chodyński], „Powieści z Nekropolis przez (...)”, „Nędzarz”, „Kaliszanin”, 1888, nr 10, s. 2.

Kaliszanin 1888, Nr 13 - Ad., [Adam Chodyński], Powieści z Nekropolis przez (...) „Ustroń cudzoziemska”, „Kaliszanin”, 1888, nr 13, s. 2.

KalisZanin 1888, NR 48 - Metalizowanie zwłok ludzkich, „Kaliszanin”, 1888, nr 48, s. 3.

Kaliszanin 1888, Nr 78 - Adam Chodyński, Nenufary, „Kaliszanin”, 1888, nr 78, s. 4

KALisZanin 1888, NR 87 - W miejsce kremacji, „Kaliszanin”, 1888, nr 87, s. 4.

KAlisZANin 1889, NR 41 - Wiadomości miejscowe i okoliczne, „Kaliszanin”, 1889, nr 41, s. 2.

Kaliszanin 1889, NR 87 - Wiadomości kościelne, „Kaliszanin”, 1889, nr 87, s. 1.

KAliszanin 1890, NR 19 - Wiadomości miejscowe i okoliczne, „Kaliszanin”, 1890, nr 19, s. 3.

KALISZANIN 1891, NR 22 - Kremacja, „Kaliszanin”, 1891, nr 22, s. 4.

Kaliszanin 1891, Nr 65 - Ad. Chod., [Adam Chodyński], Cmentarze Kalisza przez (...), „KaliSzanin", 1891, nr 65, s. 3.

Kaliszanin 1891, Nr 69 - Ad. Ch., [Adam Chodyński], Cmentarze Kalisza, „Kaliszanin” 1891, nr 69, s. 3.

Kaliszanin 1891, Nr 87 - H.W., Myśli i uwagi, „Kaliszanin”, 1891, nr 87, s. 3.

KalisZAnin 1891, Nr 102 - Serce matki, „Kaliszanin”, 1891, nr 102, s. 2.

Kaliszanin 1892, Nr 8 - Ad., [Adam Chodyński], Pod reformacką lipą ze wspomnień, „Kaliszanin", 1892, nr 8, s. 3.

Kaliszanin 1892, NR 18 - Wiadomości miejscowe i okoliczne, „Kaliszanin”, 1892, nr 18, s. 1.

KAlisZANin 1892, NR 35 - To i owo, „Kaliszanin”, 1892, nr 35, s. 4.

KAliszanin 1892, Nr 47 - H.W., Hypnotyzm i spirytyzm, „Kaliszanin”, 1892, nr 47, s. 4. 
TECHNE

T E X N H

SERIA NOWA

\section{Opracowania}

ARIEs 1989 - Philippe Aries, Człowiek i śmierć, Warszawa 1989.

B£ACHOWICZ 2003 - Maciej Błachowicz, Śmierć w dawnym Kaliszu, niepublikowana praca magisterska napisana pod kierunkiem prof. dr hab. Lecha Trzeciakowskiego, Poznań 2003, dostęp internetowy: https://www.galeriawielkopolska.info/cmentarz/mgr.pdf [dostęp: 28.12.2019].

KolbusZeWsKi 1985 - Jacek Kolbuszewski, Wiersze z cmentarza. O Współczesnej epigrafice wierszowanej, Wrocław 1985.

KolbusZewsKi 1996 - Jacek Kolbuszewski, Cmentarze, Wrocław 1996.

KunicKi 1991 - Bogumił Kunicki, Ballady kaliskie, Kalisz 1991.

MaŁYsZKo 2012 - Stanisław Małyszko, Zabytkowe Cmentarze przy Rogatce w Kaliszu, Kalisz 2012.

Nicieja 2010 - Stanisław S. Nicieja, Lwów. Ogród snu i pamięci: dzieje Cmentarza Eyczakowskiego we Lwowie oraz ludzi tam spoczywajacych w latach 1786-2010, Opole 2010.

Polanowski 1979 - Edward Polanowski, W dawnym Kaliszu. Szkice z życia miasta 1850-1914, Poznań 1979.

PolanOWSKI 1987 - Edward Polanowski, Życie literackie Kalisza 1870-1907, Warszawa 1987.

PrZYgodZKi 2012 - Sławomir Przygodzki, Kalisz wielokulturowy, Kalisz 2012.

RosıeK 1997 - Stanisław Rosiek, Zwłoki Mickiewicza. Próba nekrofagii poety, Gdańsk 1997.

VovelLe 2008 - Michel Vovelle, Śmierć w cywilizacji Zachodu od roku 1300 do wspótczesności, Gdańsk 2008.

WalCzak 2010 - Krzysztof Walczak, Adam Chodyński (1832-1902). Historyk Kalisza, Kalisz 2010. 


\section{A cemetery, a corpse and a soul as imagined by the Kalisz press in the second half of the $19^{\text {th }}$ century}

$\mathrm{T}$ he cemetery - institutionalized place for the laying of bodies, in the form known today, is the result of revolutionary changes brought about by the Enlightenment in Europe. Its main feature is the location of necropolises away from human settlements. The official action of relocating cemeteries coincided with the need to cultivate the memory of relatives who died. Such revolutionary changes could not remain unaffected by the perception of death. The article is an attempt to sketch the views, beliefs and fantasies about Christian cemeteries in the second half of the $19^{\text {th }}$ century among the Kalisz intelligentsia. The collected source material comes from "Kaliszanin", published in the years 1871-1892. Most of the analyzed texts concern cemeteries in Kalisz, but statements about other cities and those contained in literary fiction were not omitted. Due to the complexity of the issues, the focus was on three selected problems. The focus is on the perception of necropolises and their "inhabitants" - the dead. Cemeteries are places to store human remains and to cultivate the memory of the dead. However, due to their connections with eschatology, they are places that elude rational categories. The resulting ambiguity is undoubtedly worthy of the researchers' attention. Much attention was paid to people's perception of the second half of the nineteenth century of the remains already laid in the grave. It is the title "corpse". Another area of interest is the soul - a hypothetical form of human posthumous existence. In Christian culture, belief in resurrected bodies is closely related to belief in an immortal soul. The cemetery is not only a place where bodies await the resurrection, but also a zone where "ghosts" can appear to people. Hence, it is impossible to ignore the views and fantasies on this subject. At the same time, an attempt was made to interpret the collected material, hoping that this contribution would be useful for further research on the issue.

Keywords: cemeteries, eschatology, remains, spirit, Kalisz, newspapers, „Kaliszanin”, Chodyński Adam 